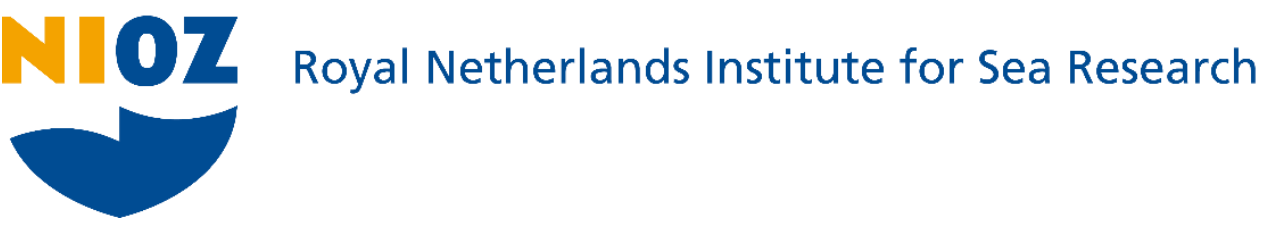

This is a postprint of:

van der Wal, D.; Lambert, G.I.; Ysebaert, T.; Plancke, Y. \& Herman, P.J.M. (2017). Hydrodynamic conditioning of diversity and functional traits in subtidal estuarine macrozoobenthic communities. Estuarine, Coastal and Shelf Science, 197, 80-92

Published version: https://dx.doi.org/10.1016/..ecss.2017.08.012

Link NIOZ Repository: $\underline{w w w . v l i z . b e / i m i s ? m o d u l e=r e f \& r e f i d=288538}$

[Article begins on next page]

The NIOZ Repository gives free access to the digital collection of the work of the Royal Netherlands Institute for Sea Research. This archive is managed according to the principles of the Open Access Movement, and the Open Archive Initiative. Each publication should be cited to its original source - please use the reference as presented.

When using parts of, or whole publications in your own work, permission from the author(s) or copyright holder(s) is always needed. 
van der Wal, D.; Lambert, G.I.; Ysebaert, T.; Plancke, Y.; Herman, P.M.J. (2017). Hydrodynamic conditioning of diversity and functional traits in subtidal estuarine macrozoobenthic communities. Estuarine, Coastal and Shelf Science 197: 80-92. https://doi.org/10.1016/j.ecss.2017.08.012

\title{
Hydrodynamic conditioning of diversity and functional traits in subtidal estuarine macrozoobenthic communities
}

\author{
Daphne van der Wal ${ }^{a^{*}}$, Gwladys I. Lambert ${ }^{a, b}$, Tom Ysebaert ${ }^{a}{ }^{c}$ \\ Yves M.G. Plancke ${ }^{d}$, Peter M.J. Herman ${ }^{a, e}$
}

${ }^{a}$ NIOZ Royal Netherlands Institute for Sea Research, Dept of Estuarine and Delta Systems, and Utrecht University, P.O. Box 140, 4400 AC Yerseke, The Netherlands

${ }^{b}$ School of Ocean Sciences, Bangor University, Menai Bridge, Anglesey LL59 5AB, United Kingdom

${ }^{c}$ Wageningen Marine Research, P.O.Box 77, 4400 AB Yerseke, The Netherlands

${ }^{d}$ Flanders Hydraulics Research, Flemish Government, Borgerhout, Antwerpen, Belgium,

${ }^{e}$ Presently at Deltares, P.O. Box 177, 2600 MH Delft, The Netherlands

*Corresponding author: daphne.van.der.wal@nioz.nl 


\section{Highlights:}

- Richness of subtidal estuarine macrofauna depended on currents and sediment properties

- Community composition and functional traits shifted with currents and sediment properties

- Salinity, water depth and distance from tidal flats had a minor effect

- Hydrodynamic models can predict hotspots and coldspots in ecological richness

\section{Graphical abstract:}

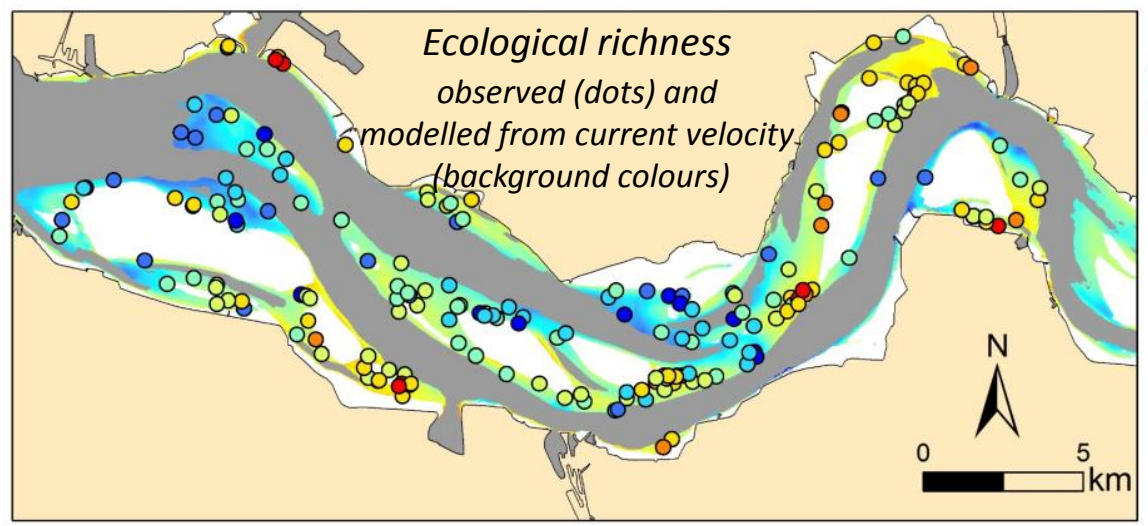

Ecological richness

2
-2

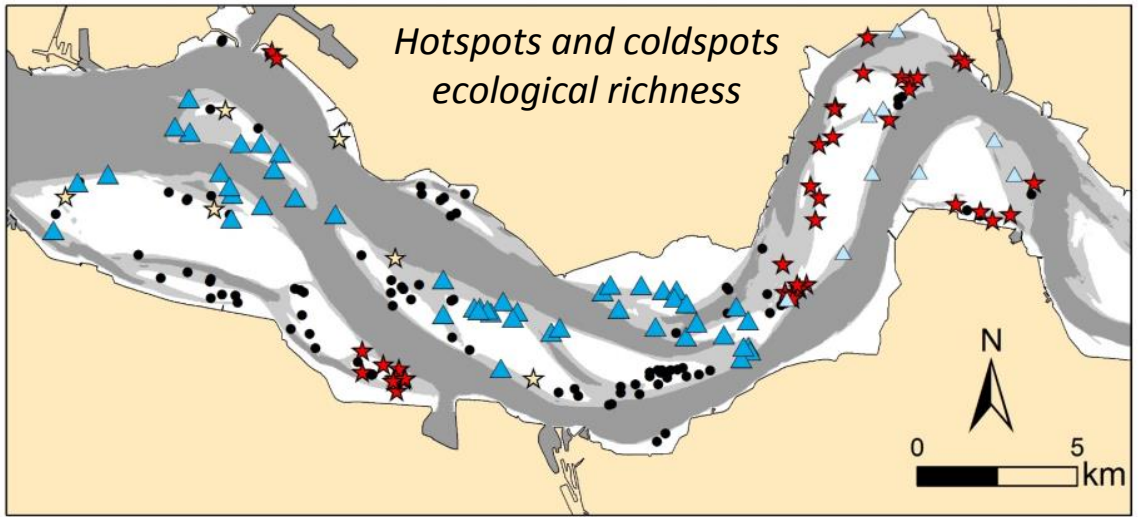

Clustering

- Not sign.

$\star \quad \mathrm{HH}$ : High clusters (hotspots)

is HL: High outlier

$\triangle \quad$ LH: Low outlier

- LL: Low clusters (coldspots) 


\begin{abstract}
Variations in abundance and diversity of estuarine benthic macrofauna are typically described along the salinity gradient. The influence of gradients in water depth, hydrodynamic energy and sediment properties are less well known. We studied how these variables influence the distribution of subtidal macrofauna in the polyhaline zone of a temperate estuary (Westerschelde). Macrofauna density, biomass and species richness, combined in a so-called ecological richness, decreased with current velocities and median grain-size and increased with organic carbon of the sediment, in total explaining $39 \%$ of the variation. The macrofauna community composition was less well explained by the three environmental variables (ca 12$15 \%$ in total, with current velocity explaining ca $8 \%$ ). Salinity, water depth and distance to the intertidal zone had a very limited effect on both ecological richness and the macrofauna community.The proportion of (surface) deposit feeders (including opportunistic species), decreased relative to that of omnivores and carnivores with increasing current velocity and sediment grain-size. In parallel, the proportion of burrowing sessile benthic species decreased relative to that of mobile benthic species that are able to swim. Correspondingly, spatial variations in hydrodynamics yielded distinct hotspots and coldspots in ecological richness. The findings highlight the importance of local hydrodynamic conditions for estuarine restoration and conservation. The study provides a tool based on a hydrodynamic model to assess and predict ecological richness in estuaries.
\end{abstract}

Key words: macrozoobenthos, estuarine gradients, functional traits, hydrodynamics, flow, Westerschelde 


\section{INTRODUCTION}

Estuaries rank among the most productive natural ecosystems on earth (Costanza et al., 1997). They are generally characterized by a relatively limited number of species that are well adapted to cope with stress, but with abundant populations (Snelgrove and Butman, 1994; Elliott and Quintino, 2007). However, species do not contribute equally to ecosystem processes and services (Stuart-Smith et al., 2013). Their contribution depends on their biological traits, such as their feeding habit and behaviour (Bremner et al., 2006; Kristensen et al., 2014). Understanding spatial patterns in the communities, as well as their functional traits is essential for management and conservation measures in estuaries.

Variation in the spatial distribution of benthic macrofauna in estuaries has been described as a function of biotic and abiotic variables. Particularly, salinity has been identified as an important driver of large-scale distribution patterns (Ysebaert et al., 2002; Giberto et al., 2004; Bremner et al., 2006; Van der Linden et al., 2012; Dutrertre et al., 2013). An early work by Remane (1934) showed that species richness was minimal at salinities of 5-7, and increased at higher salinities in the Baltic Sea. More recent work in the Baltic Sea demonstrated that these trends were accompagnied by changes in abundance, diversity and functional composition of benthic assemblages (Darr et al., 2014b). The distribution of invertebrates along the salinity gradient in estuaries is further regulated by tidal variation and salinity fluctuations (Attrill, 2002; Whitfield et al., 2012; Van der Linden et al., 2012). Statzner and Higler (1986) proposed to include flow as a driver for the zonation of benthos along the salinity gradient. Moreover, large local gradients in water depth and emersion duration, hydrodynamic energy, grain-size and mud content of the sediment may be present in estuaries, particularly in the intertidal zone. In the intertidal zone, these factors have been shown to drive changes in macrofauna community characteristics (Gray, 1974; Ysebaert \& Herman, 2002; Ellis et al. 2006; Van der Wal et al., 2008; Van Colen et al., 2010; Compton et al., 2013; Robertson et al., 2015; Cozzoli et al., 2017).

Few studies have dealt with the gradient from intertidal to subtidal zones, in part due to sampling constraints (Heip et al., 1995; Ysebaert and Herman, 2002). In particular, the often narrow transition zone between the intertidal area and deeper channels is undersampled and understudied. This shallow subtidal zone is of considerable conservation and management interest as it is a potential disposal area for dredged material from navigation channels (where

the dredged sediment is kept close to the source, while avoiding disposal on the more productive tidal flats). Ysebaert et al. (2003) found a clear decrease in macrozoobenthic biomass, density and diversity from the intertidal zone to the shallow subtidal zone of the 
Westerschelde estuary (southwest Netherlands). However, it is not clear whether this response is driven by depth sensu stricto, or by variables typically co-varying with depth (Lambert et al. 2011). Some potential influential variables could be proximity to tidal flats (benefiting from dispersal of animals or food supply from the richer adjacent intertidal flats), hydrodynamic forces and/or sediment grain-size.

Hydrological disturbance can impose strong selection forces on the biota (Rosenberg, 1995; Lytle \& Poff, 2004; Hershkovitz \& Gasith, 2013). Elliott and Whitfield (2011) argue that such strong selection applies to the estuary as a whole, and that hydrodynamics may therefore not pose a stress to the species adapted to such dynamic systems. Warwick and Uncles (1980) stated that hydrodynamics may impose a direct physical stress on infaunal communities. In addition, hydrodynamics may influence the food supply for benthic organisms (e.g., Riisgard et al., 2007), may regulate top-down control (i.e., Leonard et al., 1998) and may also regulate transport of (larval or juvenile) fauna (e.g., Snelgrove \& Butman, 1994; Haase et al., 2012). We hypothesize that in areas with high current velocities, mobile macrofauna is best adapted.

Tidal currents generally increase with water depth, while wave stress that reaches the bottom may be highest in the transition zone between the subtidal and lower intertidal area. Tidal currents and wave stress influence near-bed flow conditions for erosion, settling and deposition of sediments and hence the nature of the bottom substrate, including stability, sediment grain-size, organic matter, pore-water chemistry, and microbial content, with consequences for macrofauna (Wildish and Kristmanson, 1979; Snelgrove and Butman, 1994; Schaffner et al., 2001; Dolbeth et al., 2009).

Low current velocities facilitate the deposition of fine particles and organic material (Pearson and Rosenberg, 1978). With limited oxygenation (for example in deeper systems with stratification) this can yield anaerobic conditions in the sediment (e.g., Dauer, 2008). In areas with such large amounts of fine particles and organic material, only a few shallow living species can persist, but typically in high densities (Pearson and Rosenberg, 1978). In contrast, in more sandy sediments with little organic material, many species may co-exist, but often in much lower densities, and these species can also rework the sediment to considerable depths. A number of studies have classified the species of macrofauna in ecological groups, that are typical for a certain state of organic enrichment or disturbance (Pearson and Rosenberg, 1978; Borja et al., 2000; Robertson et al., 2015), although many of these studies were done in the context of pollution, rather than natural variations in disturbance or organic matter and sediment grain-size. We expect that the ecological group best adapted to organic enrichment is 
dominating fine, organic sediments (Pearson and Rosenberg, 1978; Robertson et al., 2015), but is also likely to be associated with lower current velocities.

As water depth, distance from tidal flats, hydrodynamic energy, and sediment grainsize vary locally in an estuary, depending on the configuration of tidal flats, shoals and channels, a patchy and heterogeneous distribution of macrofauna community characteristics may be expected, superimposed on gradual patterns of longitudinal variations in salinity, wave stress and tidal range. At a local scale, areas with relatively high abundance, species diversity or functional diversity may occur, even in estuaries that are typically characterized by relatively few species. Such local areas may be referred to as hotspots. Thus, in this paper, the term hotspot is loosely used as an area with a relatively rich macrofauna community, not to be confused with the term hotspot sensu Myers et al. (2000), used strictly for threathened biogeographic regions of extreme endemic biodiversity. Attrill et al. (1996) identified a local (relative) hotspot in the Thames estuary with over 200 invertebrate species in a heterogeneous subtidal substrate. Darr et al. (2014a) identified a number of hotspots of high bivalve biomass in the Baltic Sea, each related to specific environmental conditions. This suggests the potential importance of specific areas for estuarine functioning, e.g., for providing a habitat for macrofauna and fish, and more generally for increasing the health and resilience of the estuary. Their relevance for ecosystem functioning may likely depend on both the extent of the local hotspot and the magnitude and nature of biodiversity in macrofanua in the hotspot area.

We conducted a benthic survey targeting the shallow subtidal zone of the Westerschelde estuary (southwest Netherlands) to quantify the relationships between macrofauna and environmental variables using a spatially explicit approach. We aimed to establish (1) what environmental variables best explained the variation in density, biomass, richness, community composition and functional traits of macrofauna, and (2) whether this resulted in localised hotspots and coldspots or in gradients in ecological richness, within the estuary. We discuss how the results can be used to predict ecological richness within shallow waters.

\section{MATERIAL AND METHODS}

\section{Study area}

The Westerschelde is a funnel-shaped estuary in the southwest of the Netherlands (Fig 1), with ebb and flood channels surrounding intertidal flats. The estuary experiences a semidiurnal tide, with a mean tidal range of $3.8 \mathrm{~m}$ at the mouth, and $5 \mathrm{~m}$ at the Dutch-Belgian border 
(Eleveld et al., 2014). The estuary is turbid, well-mixed and river discharge is low, ca $100 \mathrm{~m}^{3}$ $\mathrm{s}^{-1}$ (De Vriend et al., 2011; Eleveld et al., 2014).

The estuary provides entrance to a number of ports; the main navigation channel is subject to continuous maintenance dredging and occasional capital dredging. Dredged sediment is disposed at designated locations in secondary channels, in the deeper parts of the navigation channel and in the shallow subtidal zone adjacent to the tidal. The latter is aimed to reduce current velocities near the tidal flats and to enhance sediment transport towards the tidal flats, in order to sustain the ecologically productive multiple channel system and expand ecologically valuable habitat (Plancke et al., 2014). The Westerschelde is also part of the EU Natura 2000 network that is aimed to ensure the long-term survival of Europe's most valuable and threatened species and habitats.

\section{Sampling and laboratory analysis}

Benthic samples were taken in September 2011 across the polyhaline zone of the Westerschelde (Fig. 1). A stratified random sampling scheme was adopted with three depth/current strata. We collected samples in shallow subtidal areas, based on elevation data from 2008 obtained from Rijkswaterstaat - Dutch Ministry of Infrastructure and Environment. Elevation was expressed in m NAP, where NAP is Dutch Ordnance Datum, which is about mean sea level. Two thirds of the 200 samples were taken randomly at depths between $-2 \mathrm{~m}$ NAP (ca low water tide level) and -5 m NAP. Those stations were divided equally between low dynamic and high dynamic areas, identified using habitat maps predicted from depth and current velocities (Ysebaert et al., 2009). In addition, one third of the samples was taken randomly between -10 and $-5 \mathrm{~m} \mathrm{NAP}$, regardless of current velocities. The lower limit of $-10 \mathrm{~m}$ NAP was set to exclude the deeper areas such as channels, as to provide a well-defined depth range and concentrate efforts in the thusfar undersampled shallow subtidal zone. We only sampled areas of a certain depth stratum larger than $75000 \mathrm{~m}^{2}$, to increase the chances of sampling in the targeted depth strata. Areas used to dispose dredged material (i.e., zone north of HP, west of HP and west of RB, see Fig. 1b) were not sampled, to make sure there was no direct impact of dredging activities that could have affected the macrofauna. The three strata were applied as originally labelled, even though 13 samples had depths >-2m NAP and 10 samples had depths <-10m NAP when using the 2011 bathymetric data that became available during the project. 
Samples were taken by ship with a Reineck box corer (surface area $0.0774 \mathrm{~m}^{2}, 30 \mathrm{~cm}$ depth). On board, the full boxcore sample was sieved over a $1 \mathrm{~mm}$ sieve and stored in jars and fixed with $\mathrm{pH}$ neutralised formaldehyde and stained for further analysis. While typically replicates are taken from material collected with a boxcore, thus obtaining a much smaller surface area (e.g., Van der Wal et al., 2011), in the present study we analysed the material of the entire box core to maximize the scale of support.

Animals were identified and counted at species level where possible, using recent literature, and, if needed, a reference collection managed by a taxonomist. The animals were then dried at $80^{\circ} \mathrm{C}$ for 2 days, then at $100^{\circ} \mathrm{C}$ for 1 day and then ashed for 2 hours at $580^{\circ} \mathrm{C}$ to determine biomass of each taxon (ash-free dry weight, in $\mathrm{mg} \mathrm{m}^{-2}$ ). Bivalves were weighed and their biomass was based on a regression line by dried individuals per length class. Insecta were removed from the macrofauna database. Density of the animals per taxon was expressed as individuals $\mathrm{m}^{-2}$. Average individual body mass was calculated as total biomass divided by total density per taxon.

A subsample was taken for granulometric analysis from the upper $5 \mathrm{~cm}$ of the surface of the boxcore using a small cut-off syringe. The sediment samples were freeze-dried and material $<1 \mathrm{~mm}$ was analysed using a Malvern Mastersizer 2000, capable of detecting $0.02 \mu \mathrm{m}$ to $1 \mathrm{~mm}$ grains, following the Rijkswaterstaat MONEOS protocol. From the grain-size distribution, median grain-size d50 $(\mu \mathrm{m})$ was determined. Organic carbon of the sediment was determined with a Thermo Flash 112 Elemental Analyzer. Inorganic carbon was removed by in situ acidification with ultra pure hydrochloric acid. Oven dried well grinded samples were combusted with an excess of oxygen at high temperature $\left(1020^{\circ} \mathrm{C}\right)$. Nitrous oxides were reduced to $\mathrm{N}_{2}$ on a copper column $\left(650^{\circ} \mathrm{C}\right)$. After drying, the formed $\mathrm{CO}_{2}$ and $\mathrm{N}_{2}$ gases were separated on a HaysepQ GC-column and detected with a thermal conductivity detector (TCD). Out of the 200 collected samples, 1 sediment sample was lost and 5 samples had insufficient material to determine the grain-size distribution and/or the organic carbon percentage of the sediment. Only cases with full information on all environmental variables were used in the analyses in this paper, i.e., $n=194$.

\section{Environmental variables}

Apart from grain-size and organic carbon percentage of the sediment at the sample locations, distance of the station to the nearest tidal flat, elevation, maximum current velocity and salinity were used as predictors. These were derived from raster maps. Distance of the 
sample station to the nearest tidal flat was calculated in ArcGIS 10 based on an emersion duration map from 2011 provided by Rijkswaterstaat. Elevation (m NAP) was determined based on single beam sounding in 2011 resampled to a 20 by 20 m grid by Rijkswaterstaat, coinciding with the year of sampling. Maximum current velocity during spring tide (either on the ebb or flood tide, whichever was larger) was obtained from the results of a numerical hydrodynamic model (Ides et al., 2011) using the 2011 bathymetry data as input. Modelled mean longterm salinity was obtained from Rijkswaterstaat.

\section{Univariate macrofaunal indices}

Density and biomass were expressed per $\mathrm{m}^{2}$. Species richness was expressed as the total number (sum) of taxa in a sample. Family level taxa were only counting as a separate taxon if specimen were not already identified at the genus level for that sample, and genus level taxa were only counted as a separate taxon if specimen were not already identified at the species level for that sample. For example, when Limecola and Limecola balthica were both present, they were counted as one taxon. Note that species richness per sample, but also density per $\mathrm{m}^{2}$ and biomass per $\mathrm{m}^{2}$ are all relative measures, depending on the sample size, and hence care should be taken when comparing the values with those from other studies. Table 1 gives a statistical summary of the univariate measures.

To meet the statistical assumptions of the regression (see section on univariate analyses) and the relatively less stringent multivariate analyses, values for macrobenthic biomass, density and species richness were $\log$-transformed as $\ln (\mathrm{x}+1)$. Since biomass, density and species richness were correlated (Supplementary Material S4), but with some degree of variation, the three variables were standardized and combined into a relative integrative univariate measure of ecological richness for each sample (Ysebaert et al., 2009), defined as $\frac{\frac{(B-\bar{B})}{s d(B)}+\frac{(D-\bar{D})}{s d(D)}+\frac{(S-\bar{S})}{s d(S)}}{3}$, where B is log-transformed biomass, D is log-transformed density and S is log-transformed species richness of benthic macrofauna, averages are denoted with bars and sd is the standard deviation. Ecological richness is used here as an additional univariate ecological indicator. Its value centres around 0 (by definition) for average ecological richness in a given data set, and for our data set ranges from -3.69 (low ecological richness) to 2.52 (high ecological richness). Thus, ecological richness is a relative measure; "high" ecological richness may be associated with samples having very little species, low densities and/or low biomasses, when the system or data set is overall poor in macrofauna. Ecological richness is used here to express relative differences in macrofauna richness within the estuarine system. 


\section{Functional traits}

Information on functional traits comprised of feeding habit, mobility and life history strategy of each taxon. The feeding habit (i.e. surface deposit feeders, deposit feeders, suspension feeders, omnivores, carnivores/predators and herbivores and other, respectively) of taxa was obtained from the NIOZ BIS database; more than $99 \%$ of both total density and biomass in our 194 samples could be assigned a trait.

Regarding the mobility trait, the primary and secondary sources of information were the MarLIN BIOTIC database (MarLIN, 2006; http://www.marlin.ac.uk/biotic) and the Polytrait database (Faulwetter et al., 2014; http://polytraits.lifewatchgreece.eu). Additional taxonomic information was obtained from WoRMs (WoRMS, Editorial Board, 2014; http://www.marinespecies.org) and the Genus Trait Handbook (http://www.genustraithandbook.org.uk). We distinguished sessile/attached taxa (A), burrowers (B), crawlers (C), swimmers (S) and taxa with unknown traits (U). When taxa had more than one mobility trait, combinations including swimmers ("mixed, swimmers") and combinations without swimmers ("mixed, non swimmers") were distinguished. When speciesspecific information was unavailable, mobility traits were assigned from that of a lower or higher taxonomic level (i.e., for Abra albra, Arenicola marina, Crangon crangon, Pseudopolydora pulchra, Myra arenaria, Spisula subtruncata, Streblospio benedicti, Nephtys spp. and Spio martinensis), or to other species within the same genus (i.e., for Bathyporeia, Corophium and Ensis). Actiniaria, Bryozoa and Sessilia were assumed to be sessile/attached. The mobility trait was established for $95 \%$ of the total density and $99 \%$ of the total biomass.

We also derived ecological groups (EG) from the species/taxa list used in the AZTI Marine Biotic Index AMBI (AZTI, 2015; http://ambi.azti.es). AMBI offers a pollution, organic enrichment, environmental stress or disturbance classification using theory on the adaptive strategies of species and is widely used as part of assessments of the ecological quality of cosatal and estuarine ecosystems (Borja et al., 2000). Group EG-I denotes species sensitive to organic enrichment or disturbance, EG-II species indifferent to excess organic matter, EG-III species tolerant to excess organic matter, EG-IV second-order opportunistic species, and EGV first-order opportunistic species (Borja et al., 2000). The groups represent life history strategies ranging from slow-growing K-selected species in EG-I, EG-II and EG-III, to fastgrowing opportunistic r-selected species in EG-IV and EG-V. In our study, 99\% or more of both total density and biomass could be assigned to an ecological group. 
Table 2 lists the traits of a selection of taxa commonly found in this study. Densities and biomasses of all taxa of a specific trait modality were summed for each station and used in the functional trait analyses.

\section{Multivariate analyses: response of the macrofaunal community composition and functional traits to environmental variables}

A multivariate analysis was performed to assess the response of the macrofaunal community composition to environmental variables. To avoid ambiguity, specimens that had only been determined at class or phylum level were left out for this multivariate analysis. Nemertea and Oligochaeta were included. If not all specimen of a genus were identified at the species level, they were merged to the genus level. The species name was then added in parentheses when only one species was identified within the genus in all samples, whereas spp. was used when multiple species were present. In some stations, one individual of a specific taxon was counted with $0 \mathrm{mg} \mathrm{m}^{-2}$ biomass. As a result, 87 (density-based) and 81 (biomassbased) taxa were included in the multivariate analyses.

The community structure was analyzed using multivariate statistics in the software package PRIMER, version 6.1.12 (Clarke \& Warwick, 1994). Dominance plots of all samples were drawn to illustrate how many taxa contributed to the total density. Bray-Curtis similarity matrices were constructed (Clarke, 1993) from log-transformed density and log-transformed biomass of the macrobenthic taxa, respectively. The multivariate biological patterns were then related to the environmental variables using BEST in PRIMER. For these analysis, environmental variables were normalized and a Euclidean distance measure was applied. The BIOENV routine in BEST was used to quantify the correlation of all environmental variables with the macrofauna community, and to evaluate the correlation of each single variable with the macrofauna community, respectively. Subsequently, the BVSTEP routine indicated which combination of environmental variables best explained the macrobenthic community, in a stepwise search. A Spearman rank analysis with a permutation test (999 permutations) was used to assess significance (with a significance level of $\mathrm{P}<0.05$ ). A similar procedure was followed to correlate the log-density and log-biomass of specific functional trait modalities with the environmental variables. Taxa with an unknown modality for a specific trait were left out for that analysis.

The contribution of each normalized environmental variable to the total macrofauna community, based on log-transformed density and log-transformed biomass of macrofauna taxa respectively, was investigated further using the Adonis routine in the package Vegan 2.4- 
3 (Oksanen et al., 2017) in the statistical environment R. A permutational multivariate analysis of variance was carried out using a Euclidean distance matrix. Significance of the contribution of each environmental variable $(\mathrm{P}<0.05)$ was tested with a permutation test ( 999 permutations).

\section{Univariate analyses: response of the macrofaunal indices to environmental variables}

Univariate statistical tests were performed in the statistical environment R. To gain insight into the correlation among environmental variables, Pearson product-moment correlations were calculated among each pair of environmental variables; a criterion of $\mathrm{P}<0.05$ was used to identify significance. Statistical differences in the macrofauna indices of the three current/depth strata were tested in an ANOVA, followed by a posthoc Tukey test.

Linear single and multiple regressions ( $\mathrm{lm}$ in $\mathrm{R}$ ) were applied to test the response of univariate macrofauna indices to the environmental variables. A stepwise forward multiple regression was used to eliminate redundant variables. A Variance Inflation Factor (VIF) was calculated for each of the remaining variables in the multiple regression models to detect multicollinearity $\left(\mathrm{VIF}>\sqrt{2}\right.$ ). A coefficient of determination $R^{2}$ was calculated to compare performance of the single models. For multiple regressions, the coefficient of determination was adjusted for the number of coefficients, $R_{a d j}^{2}$, and performance of the models was compared using Akaike's Information Criterion (AIC) (Sakamoto et al. 1986); smaller values of the AIC indicate a better model. No Bonferroni correction was applied. Prerequisites for the regression were inspected, i.e. that residuals were not autocorrelated (Durbin Watson test), that residuals were homoscedastic (Breusch-Pagan test) and that residuals were distributed normally (Shapiro Wilk's test). In case of rejection of these assumptions $(\mathrm{P}<0.05)$, visual inspection of quantile plots and histograms of residuals indicated that application of a specific regression model was nevertheless acceptable.

Maximum current velocity and sediment grain-size were the best predictors for all macrofaunal indices in the tests. Therefore, the focus of the univariate trait analysis was put on these two environmental variables. Significant $(\mathrm{P}<0.05)$ linear regression models and their 95\% confidence limits were calculated and plotted to highlight these trends. Either total density or biomass of taxa with a specific trait modality were plotted as dependent variable. Environmental variables, such as currrent velocity, were plotted as the independent variable. To further visualise overall trends in macrofauna indices along these environmental gradients, the mean, and $95 \%$ confidence limits of the mean of density and biomass of all traits were also 
calculated for 10 classes ranked by the value of the environmental variable, with ca 20 sample observations in each class.

\section{Spatial distribution of ecological richness along the hydrodynamic gradient}

The regression model with ecological richness as the dependent variable and maximum current velocity as the independent variable was applied to estimate the spatial distribution of ecological richness from spatial information on hydrodynamics in the study area. This model was selected as it was the best model based on environmental variables with spatial coverage.

To identify significant spatial patterns in ecological richness, spatial cluster analysis based on Anselin Local Moran's I statistic was performed in ArcGIS 10.5 (Anselin, 1995; ESRI, 2016). Local Moran's $I$ index, $z$-score, $P$-value, and cluster/outlier type were calculated for each sample location to indicate whether the apparent similarity (spatial clustering) or dissimilarity (spatial outlier) was more pronounced than one would expect from a random distribution. A significant high positive z-score for a sample station indicated that the surrounding sample stations had similar values (either high values, i.e., hotspots or low values, i.e. coldspots). A significant negative $z$-score $(z<-1.96)$ for a sample station indicated a spatial outlier, either a high value surrounded by stations with low values (outlier type HL) or a low value surrounded by stations with high values (outlier type LH). Spatial relationships were conceptualized using an inverse Euclidean distance function, with no maximum distance set.

In PRIMER (Clarke \& Warwick, 1994), a multivariate analysis (i.e., SIMPER) of the log-transformed densities of the macrofauna community was performed to identify the contribution of each taxon to average (Bray-Curtis) dissimilarity between the cluster groups.

\section{RESULTS}

Multivariate analyses: response of the macrofaunal community composition and functional traits to environmental variables

Maximum current velocity and median grain-size of the sediment were the best predictors of community composition, in single predictor variable models (Table 3). Feeding habit, mobility trait and the life history strategy of the community had the strongest correlation with current velocity when based on biomass, and sediment grain-size when based on density (Table 3). Elevation, organic carbon percentage of the sediment, distance to the tidal flat and salinity had a considerably weaker effect on the community structure (Table 3). A combination of environmental variables best explained the macrobenthic community composition and the 
functional traits; current velocity and median grain-size were always significant predictors in these combinations (Table 3). The models had relatively low Spearman rank correlations $(\rho<$ $0.4)$.

The permutational multivariate analysis of variance showed that all variables except distance to the tidal flat contributed significantly to explaining the total community composition of the macrofauna, both when based on log-density and on log-biomass (Supplementary Table S1). Maximum current velocity explained most variation (ca 8\%), followed by salinity (4-5\%), median grain-size (2-4\%) and organic carbon percentage of the sediment (3\%). Ca 77\% (density-based) to $80 \%$ (biomass-based) of the variation in the macrofauna community remained unexplained by the environmental variables.

\section{Univariate analyses: response of the macrofaunal indices to environmental variables}

The three depth/current strata had a significantly different macrofauna (Supplementary Material S2). Tukey tests show that the stations ">-5 m NAP, low dynamic" were consistently richer (i.e., had higher values of macrofauna density, biomass, species richness and ecological richness) than the stations " $>-5 \mathrm{~m} \mathrm{NAP}$, high dynamic" and " $<-5 \mathrm{~m}$ NAP", while there was no statistical difference between the stations " $>-5 \mathrm{~m}$ NAP, high dynamic" and "<-5 m NAP".

Macrofauna density, biomass, species richess and the composite univariate measure ecological richness were all negatively related to current velocity, median grain-size and to a lesser extent to distance to the tidal flat and salinity (Supplementary Material S3). They were positively related to organic carbon percentage of the sediment and elevation (Supplementary Material S3), although relationships were weak (Table 4). Of all environmental variables, maximum current velocity explained most variation in the macrofauna indices as a single variable in a linear regression (up to 37\%), whereas organic carbon percentage of the sediment and salinity explained least (Table 4). Maximum current velocity, median grain-size and organic carbon percentage of the sediment were included in each of the best multiple regression models explaining the macrofauna indices (Table 4). Most of the environmental variables were significantly correlated among each other. Notably, elevation decreased with distance from the tidal flat $(\mathrm{r}=-0.59)$. Coarser median grain-sizes of the sediment were associated with higher maximum current velocities $(\mathrm{r}=0.57)$ and lower organic carbon percentages $(\mathrm{r}=-0.58)$ (Supplementary Material S5). 
Given the relatively strong response of the macrofaunal indices to maximum current velocity and sediment grain-size, we investigated in detail how functional traits varied with these two variables (Fig. 2 and 3). Organic carbon percentage was not a good single predictor for the macrofaunal indices, but since it contributed significantly to the stepwise multiple regressions, the trait responses to organic carbon were also investigated (Supplementary Material S6).

(Surface) deposit feeders (such as Heteromastus filiformis, Aphelochaeta marioni and Scoloplos armiger) and suspension feeders (such as Spio martinensis, Actiniaria and Ensis (directus)) were negatively related to currents, whereas carnivores and omnivores (such as Nemertea and Nephtys spp.) were not significantly related to currents (Fig 2a,b). This resulting in a shift of the trophic structure with increasing current velocity. (Surface) deposit feeders and suspension feeders dominated environments with low current velocities. In contrast, groups that were not significantly sensitive to current velocities, i.e., the carnivores and omnivores, dominated environments with high current velocities. A similar trophic shift was apparent with increasing sediment grain-size (Fig. 3). Omnivores and carnivores were also less abundant in sediments with higher organic matter contents, whereas (surface) deposit feeders increased with organic matter content (Supplementary Material S6).

Density and biomass of the macrofauna decreased with current velocity, but the rate of change varied for each of the mobility modalities (Fig 2c, d). As a result, at low current velocities, burrowers (such as Aphelochaeta marioni, Capitella capitata and Scoloplos armiger) dominated, whereas at high current velocities, mobile taxa (such as Nephtys spp. and Gastrosaccus (spinifer) that were also able to swim dominated.

Regarding the life history strategy, most ecological groups declined in density and biomass with current velocity (Fig. 2) and grain-size (Fig. 3), but to a variable degree. Hence, at low currents and in fine sediments, EG-III and EG-IV dominated, whereas at high current velocities and in coarse sediments, EG-I and EG-II and EG-III dominated. Ecological groups responded differently to an increase in organic carbon (Supplementary Material S6). With increasing organic carbon of the sediment, the opportunists EG-IV and EG-V increased in density and biomass, group EG-II with indifferent species declined, and group EG-I with sensitive species declined in biomass only (Supplementary Material S6).

Thus, in the area under study, macrofauna density and biomass of many functional groups appeared to be restricted by high current velocities and coarse sediment. In the finest sediment class, a number of feeding groups, mobility modalities and ecological groups appeared to be restricted in biomass relative to the slightly coarser sediment classes. At stations 
with relative high organic matter (organic matter $>1 \%$, co-inciding with median grain-sizes $<35 \mu \mathrm{m}$, mud contents $>50 \%$ ), groups sensitive and indifferent to organic enrichment appeared to be restricted.

\section{Spatial distribution of ecological richness along the hydrodynamic gradient}

Ecological richness was best explained by maximum current velocity $v$ as a single variable $\left(-0.0159 v+1.868, F_{1,192}=111.7, R^{2}=0.37, n=194, P<<0.001\right)$, explaining just $2 \%$ less variation than the multiple regression with current velocity, median grain-size and organic carbon of the sediment (i.e., 37\% versus 39\%, Table 3). Fig. 4a shows the observed ecological richness, and the spatial model prediction of ecological richness based on current velocity for the entire Westerschelde. The high observed values of ecological richness near MS, west RB, near MP and east of PO were well estimated by the model (yellow areas in Fig. 4a, see Fig. 1 for location names). The low observed values of ecological richness at SP, around HP, north of MI and and south of PB were also well estimated by the model (blue areas in Fig 4a).

Coldspots, i.e., areas with low ecological richness, were found around the large tidal flat at the mouth (west of HP), and in the centre of the study area (around MI, PB, RB), and hotspots were found in the centre (around MS) and in the east (near RB and MP), whereas an area with low outliers was also observed in the east (Fig. 4b). These patterns corresponded to the areas with high and low tidal current, as indicated in the ecological prediction map in Fig. 4a as blue and yellow areas, respectively.

The number of taxa was slightly higher in the hotspots (on average 12.1 taxa in the 40 hotspot samples) than in the coldspots (on average 4.2 taxa in the 48 coldspot samples) (see also taxa dominance in Supplementary Material S7). Analysis of similarity (SIMPER) showed that the 68 taxa that were more abundant in the hotspots than in the coldspots (including for example Heteromastus filiformis, Aphelochaeta marioni, Limecola balthica, Scoloplos armiger, Capitella capitata and Spio) together contributed $85.8 \%$ to the dissimilarity in samples of the hotspots versus those in the coldspots. In contrast, the 13 taxa that were more abundant in the coldspots than in the hotspots (i.e., Nemertea, Magelona, Gastrosaccus (spinifer), Mysidae, Parahaustorius holmesi, Ophelia, Mesopodopsis slabberi, Schistomysis kervillei, Pontocrates altamarinus, Spionidae, Micropthalmus, Cirrutilidae and Paraonidae), together contributed $14.2 \%$ to the dissimilarity between hotspots and coldspots.

\section{DISCUSSION}


Macrofauna indices, community composition and functional traits were estimated as a function of environmental variables in the estuarine shallow subtidal zone. Maximum current velocity best explained macrofauna density, biomass, species richness and ecological richness as well as the macrofaunal community composition as a single variable, closely followed by median grain-size of the sediment. Areas with lower current velocities and fine sediments were characterised by higher densities, biomasses and species richness of macrofauna. In multiple regressions, current velocity, median grain-size and organic carbon percentage of the sediment were always significant predictor variables, and they explained up to $39 \%$ of the total variation. Elevation (c.q. water depth), salinity and distance to the tidal flats explained little variation in macrofauna. In contrast to Remane (1934)'s findings who predicted a linear increase in species diversity with increasing salinity in the polyhaline and marine zone, we found a weak (but significant) decrease in species richness with salinity in this limited salinity range. The impact of hydrodynamics (which correlates positively with salinity in our study site) likely overruled salinity effects.

The environmental variables explained little variation in the macrofauna community (current velocity and median grain-size together explained ca 10\%). Nevertheless, we found a trophic shift from a (surface) deposit feeder dominated community (with species such as Heteromastus filiformis, Scoloplos armiger, Aphelochaeta marioni and Limecola balthica) to a predator and omnivore dominated community (such as Nephtys spp) with increasing current velocities and sediment grain-size. In particular deep deposit feeders (as well as surface deposit feeders and suspension feeders) had low abundance in areas with strong currents throughout the estuary. The proportion of swimmers and crawlers increased relative to that of burrowers with increasing current velocity, indicating that current velocity selected for mobile species. Shifts in community composition related to hydrodynamics have also been observed elsewhere, albeit with a diverse outcome. In many studies, surface deposit feeders are generally associated with little hydrodynamic action on the sediment bed, as currents limit their feeding and mobility (Wildish and Kristmanson, 1997; Dolbeth et al., 2009), and high energy conditions may flush them out. Deep living deposit feeders are often associated with areas with no significant hydrodynamic impact and high organic matter sediments (Rosenberg, 1995), although Wildish and Kristmanson (1997) found that the deep burrowing deposit feeders, such as Scoloplos armiger and Spiophanes bombyx, also occurred in the high energy regions. Van Colen et al. (2010) also revealed a shift in macrofauna community towards a deeper living position and a decrease in species richness with increasing hydrodynamic stress on a tidal flat in the Westerschelde. At a depth gradient along the seafloor of southern Portugal, Dolbeth et al. 
(2009) found a large proportion of deposit feeders in very deep areas, where waves were not felt.

The spatial heterogeneity in densities, biomass, species richness, community structure and functional traits of macrofauna within the estuary has potential implications for ecosystem functioning. In estuaries, macrofauna community structure regulates ecosystem functioning through, for example, biophysical processes, such as bioturbation and bioirrigation (Biles et al., 2002; Braeckman et al., 2010), and biogeochemical processes, such as nutrient cycling (Kristensen et al., 2014). Such processes can be expected to be more intense in the hotspots with a more diverse and abundant macrofauna community dominated by burrowers. In addition, the subtidal hotspots can function as habitat for both macrofauna and (demersal) fish. Many flatfish species feed preferentially on endobenthic macrofauna (e.g., Hartley, 1940; Hostens and Mees, 1999) and can use the hotspots as additional feeding grounds in addition to the tidal flats and marsh creeks. In contrast, gadoids, gobies and clupeoids may rely more on mobile hyperbenthic species (e.g., mysids) and epibenthic macrofauna (Hostens and Mees, 1999), which were characteristic for the high dynamic coldspots.

Despite spatial variation in ecological richness within the estuary, our study reveals that the community in the shallow subtidal zone of the Westerschelde estuary is dominated by a few macrofaunal species. Cozzoli et al (2013) show that, compared to the nearby Oosterschelde estuary, density and species richness in the Westerschelde estuary as a whole are small. Although the shallow subtidal zone is richer than the deeper parts, abundance, biomass and richness can be considered relatively low compared to the intertidal zone (Ysebaert et al., 2003; Van der Wal et al., 2011). Results confirm earlier studies stating that estuaries are dominated by relatively few organisms that have the complex adaptations necessary to survive high levels of environmental stress (e.g., Schaffner et al., 2001; Elliott and Whitfield, 2011). However, our study reveals that even within such systems with very limited species richness, pronounced gradients in the relative abundance of these few species occur along the hydrodynamic stress gradient. In contrast to the hypothesis put forward by Elliott and Whitfield (2011), we therefore conclude that hydrodynamics can still be considered a stress to most macrofaunal species in the estuary.

This study can therefore have important ramifications not only for the Westerschelde estuary, but for estuaries and deltas worldwide, particularly for those with a macrotidal regime, as these can have large spatial heterogeneity in hydrodynamic forces. The results demonstrate that spatially explicit information on hydrodynamics may be used for the prediction of such stress to macrofauna species and communities. This corroborates earlier studies that have 
included model predictions of tidal currents in habitat mapping, such as Warwick and Uncles (1980) for Bristol Channel, Dutertre et al. (2013) for South Brittany and Schückel et al. (2015) for the Wadden Sea. Exact relationships and the importance of other variables such as sediment grain-size, organic matter and water depth, however, may depend on the community attributes, site and spatial scale. The apparent importance of variables may depend on the range of conditions encountered in a specific basin. In the part of the Westerschelde estuary studied in this paper, salinity only ranged from 16 to 29 , i.e., less than doubled, whereas maximum current velocity varied from 0.49 to $2.10 \mathrm{~m} / \mathrm{s}$, i.e., more than a fourfold difference. By design, our study was also limited to the shallow subtidal zone.

The approach should be evaluated for robustness by data from other estuaries. Data from multiple estuaries can enlarge the range of values for each environmental variable, and for ecological richness. Such an approach may also explain differences in the macrofauna community among basins. For example, Josefson and Hansen (2004) used a common sampling approach for assessing the role of saltwater fluxes on species richness in Danish estuaries and coastal areas.

Methods to detect and quantify ecological quality are required for estuarine monitoring and assessment programmes worldwide (Robertson et al., 2015); they can be based on biological indicators (such as species richness and the proportion of ecological groups with varying sensitivity and tolerance to organic enrichment or disturbance), physical indicators (such as hydrodynamics and sediment grain-size) or both (e.g., Puente and Diaz, 2008). With model output from hydrodynamic models being increasingly available for estuaries and deltas, the combined physical-biological approach outlined in our paper has potential to support spatial predictions, for example of the impact of natural changes and human interventions (such as dredging) on benthic macrofauna.

Our study reveals that the macrofauna abundance and species richness was highest in relatively low energy environments with fine sediments. This seems, at first glance, in contrast to studies using benthic indicators (e.g., Pearson and Rosenberg, 1978; Borja et al., 2000; Robertson et al., 2015), that show less diverse and more opportunistic macrozoobenthic communities (i.e., lower ecological quality) in fine, muddy, low flow environments. However, Ysebaert et al. (2002) show that in the Westerschelde estuary as a whole, many macrozoobenthic species have their optimum at maximum ebb current velocities below the range of maximum current velocities encountered in our study of the shallow subtidal zone. The shallow subtidal zone thus typically represents the higher flow regimes of the full current velocity range. In our study area, areas that score only intermediate on quality indices based on 
ecological groups, such as AMBI, have the highest biomass, density and species richness of macrofauna. Hydrodynamics appears to be the primary determinant of biodiversity, restricting biomass, density and species richness at higher current velocities. Relatively calm areas coincide with the areas of fine sediment that contains highest organic matter contents (cf. Dauvin and Ruellet, 2009). A number of the species that are characteristic of such fine sediments, that score only intermediate on quality indices, are restricted at higher current velocities. Comparable results can also be expected in other transitional waters with a large spatial variability in hydrodynamic forces.

Estuaries change constantly, both as a result of natural and anthropogenic drivers, such as dredging. As morphology changes, so will hydrodynamics, which is expected to result in changes in the position and extent of coldspots and hotspots of ecological richness, and in shifts in community composition. For example, an increase in current velocity in the shallow subtidal zone is expected to reduce the ecological richness of the macrofauna. A reduction of current velocities in the shallow subtidal zone on the other hand is expected to yield an estuarine macrozoobenthos community that has a higher density, biomass and number of species of macrofauna, until a point where very high mud contents and organic enrichment could reduce macrofauna biomass.

\section{CONCLUSIONS}

We found that current velocity and sediment grain-size best explained the macrofaunal community composition and functional traits in the estuarine subtidal zone. These environmental variables were negatively related to macrofaunal density, biomass, species richness and ecological richness. Salinity, distance to the tidal flats and elevation had considerably less effect on macrofauna. The variations in particularly current velocity resulted in distinct hotspots and coldspots of ecological richness in the estuary. The ecological richness can be estimated in a spatially explicit way from hydrodynamic models. The study shows that local physical conditions are highly important for ecology in estuaries with a complex spatial configuration of tidal flats, shoals and channels. These local conditions should therefore be taken into account in estuarine management.

\section{ACKNOWLEDGEMENTS}

Sampling for this study was funded by Rijkswaterstaat, in the framework of the MONEOS Westerschelde programme. We thank Dick J. de Jong, Marco Schrijver and Silvana Ciarelli of Rijkswaterstaat, Zee and Delta (ZD), and Saa Henry Kabuta of Rijkswaterstaat, 
Water, Verkeer en Leefomgeving (WVL), Lelystad. GIL was funded by a FP7 Euromarine Mobility Fellowship. We thank the Monitor Taskforce of the Royal Netherlands Institute for Sea Research, in particular the analysts for sampling and macrofauna determination, and Vincent Escaravage for providing the macrofauna data set. Johan Craeymeersch of IMARES, Yerseke, helped with taxonomic rules. Gwendy Vos (Flanders Hydraulics Research/Antea Group) provided the current velocity data from hydrodynamic modelling.

The data associated with this paper is made available at http://doi.org/10.4121/uuid:5ca4beee-b292-4560-87c6-de1ae6c067b0.

Author contributions: DVDW, TY and PMJH conceived the macrofauna sampling design, YMGP contributed hydrodynamic model data, DVDW and GIL analysed the data, DVDW wrote the manuscript, and all authors commented on the paper. 


\section{LITERATURE CITED}

Anselin, L., 1995. Local Indicators of Spatial Association - LISA. Geographical Analysis 27, 93-115.

Attrill, M.J., 2002. A testable linear model for diversity trends in estuaries. Journal of Animal Ecology 71, 262-269.

Attrill, M.J., Ramsay, P.M., Thomas, R.M., Trett, M.W., 1996. An estuarine biodiversity hotspot. Journal of the Marine Biological Association of the United Kingdom 76, 161-175.

AZTI, 2015. AZTI Marine Biotic Index (AMBI), AMBI species list version W8, November 2014, http://ambi.azti.es. Last accessed 15 August 2015.

Biles, C.L., D.M. Paterson, R.B. Ford, M. Solan and D.G. Raffaelli, 2002. Bioturbation, ecosystem functioning and community structureHydrology and Earth System Science, 6, 999-1005.

Borja, A., Franco, J., Pérez, V., 2000. A marine biotic index to establish the ecological quality of soft-bottom benthos within European estuarine and coastal environments. Marine Pollution Bulletin 40, 1100-1114.

Braeckman U, P. Provoost, B. Gribsholt, D. van Gansbeke, J.J. Middelburg, K. Soetaert, M. Vincx, J. Vanaverbeke. 2010. Role of macrofauna functional traits and density in biogeochemical fluxes and bioturbation. Marine Ecology Progress Series 399: 173-186.

Bremner, J., Rogers, S.I., Frid, C.L.J., 2006. Matching biological traits to environmental conditions in marine benthic ecosystems. Journal of Marine Systems 60, 302-316.

Clarke, K.R., 1993. Non-parametric multivariate analyses of changes in community structure. Australian Journal of Ecology 18, 117-143.

Clarke, K.R., Warwick, R.M., 1994. Change in marine communities: an approach to statistical analysis and interpretation. Plymouth Marine Laboratory, Plymouth, UK, 144 pp.

Compton, T.J., Holthuijsen, S., Koolhaas, A., Dekinga, A., ten Horn, J., Smith, J., Galama, Y., Brugge, M., van der Wal, D., van der Meer, J., van der Veer, H.W., Piersma, T., 2013. Distinctly variable mudscapes: Distribution gradients of intertidal macrofauna across the Dutch Wadden Sea. Journal of Sea Research 82, 103-116.

Costanza, R., d'Arge, R., de Groot, R., Farber, S., Grasso, M., Hannon, B., Limburg, K., Naeem, S., O'Neill, R.V., Paruelo, J., Raskin, R.G., Sutton, P., van den Belt, M., 1997. The value of the world's ecosystem services and natural capital. Nature 387, 253-260. 
Cozzoli, F., Bouma, T.J., Ysebaert, T., Herman, P.M.J. (2013). Application of non-linear quantile regression to macrozoobenthic species distribution modelling: comparing two contrasting basins. Marine Ecology Progress Series 475, 119-133

Cozzoli, F., Smolders, S., Eelkema, M., Ysebaert, T., Escaravage, V., Temmerman, S., Meire, P., Herman, P.M.J., Bouma, T.J. (2017). A modeling approach to assess coastal management effects on benthic habitat quality: A case study on coastal defense and navigability. Estuarine, Coastal and Shelf Science, 184: 67-82.

Darr, A., Gogina, M., Zettler, M.L., 2014a. Functional changes in benthic communities along a salinity gradient - a western Baltic case study. Journal of Sea Research 85, 315-324.

Darr, A., Gogina, M., Zettler, M.L., 2014b. Detecting hot-spots of bivalve biomass in the southwestern Baltic Sea. Journal of Marine Systems 134, 69-80.

Dauer, D.M., Llanso, R.J., Lane, M.F., 2008. Depth-related patterns in benthic community condition along an estuarine gradient in Chesapeake Bay, USA. Ecological Indicators $8,417-424$.

Dauvin, J.C., Ruellet, T., 2009. The estuarine quality paradox: Is it possible to define an ecological quality status for specific modified and naturally stressed estuarine ecosystems? Marine Pollution Bulletin 59: 38-47.

Dutertre, M., Hamon, D. Chevalier, C. Ehrhold, A., 2013. The use of relationships between environmental factors and benthic macrofaunal distribution in the establishment of a baseline for coastal management. ICES Journal of Marine Science 70, 294-308.

De Vriend H.J., Wang, Z.B., Ysebaert, T., Herman, P.M.J., Ding, P., 2011. Eco-Morphological Problems in the Yangtze Estuary and the Western Scheldt. Wetlands 31, 1033-1042.

Dolbeth, M., Teixeira, H., Marques, J.C., Pardal, M.A., 2009. Feeding guild composition of a macrobenthic subtidal community along a depth gradient. Scientia Marina 73, 225-237.

Eleveld, M.A., D. van der Wal, T. van Kessel (2014). Estuarine suspended particulate matter concentrations from sun-synchronous satellite remote sensing: Tidal and meteorological effects and biases. Remote Sensing of Environment, 143, 204-215.

Elliott, M., Whitfield, A.K. (2011) Challenging paradigms in estuarine ecology and management. Estuarine, Coastal and Shelf Science 94, 306-314.

Elliott, M., Quintino, V. 2007. The estuarine quality paradox, environmental homeostasis and the difficulty of detecting anthropogenic stress in naturally stressed areas. Marine Pollution Bulletin 54, 640-645. 
Ellis, J., Ysebaert, T., Hume, H., Norkko, A., Bult, T., Herman, P., Thrush, S., Oldman, J., 2006. Predicting macrofaunal species distributions in estuarine gradients using logistic regression and classification systems. Marine Ecology Progress Series 316, 69-83.

ESRI, 2016. Cluster and Outlier Analysis (Anselin Local Moran's I) (Spatial Statistics). ArcGIS resources. http://resources.arcgis.com/en/communities/. Last accessed 10 October 2016.

Faulwetter, S., Markantonatou, V., Pavloudi, C., Papageorgiou, N., Keklikoglou, K., Chatzinikolaou, E., Pafilis, E., Chatzigeorgiou, G., Vasileiadou, K., Dailianis, T., Fanini, L., Koulouri, P., Arvanitidis, C., 2014. Polytraits: A database on biological traits of marine polychaetes. Biodiversity Data Journal 2: e1024. doi:10.3897/BDJ.2.e1024

Giberto, D.A., Bremec, C.S., Acha, E.M., Mianzan, H., 2004. Large-scale spatial patterns of benthic assemblages in the SW Atlantic: the Rio de la Plata estuary and adjacent shelf waters. Estuarine, Coastal and Shelf Science 61, 1-13.

Gray, J.S., 1974. Animal-sediment relationships. Oceanography and Marine Biology: an Annual Review 12, 223-261.

Haase, A.T., Eggleston, D.B., Luettich, R.A., Weaver, R.J., Puckett, B.J., 2012. Estuarine circulation and predicted oyster larval dispersal among a network of reserves. Estuarine, Coastal and Shelf Science 101, 33-43.

Hartley, P.H.T., 1940. The Saltash tuck-net fishery and the ecology of some estuarine fishes. Journal of the Marine Biological Association of the United Kingdom 24, 1-68.

Heip, C.H.R., Goosen, N.K., Herman, P.M.J., Kromkamp, J., Middelburg, J.J., Soetaert, K., 1995. Production and consumption of biological particles in temperate tidal estuaries. Oceanography and Marine Biology - An Annual Review 33, 1-149.

Hershkovitz, Y., Gasith, A., 2013 Resistance, resilience, and community dynamics in mediterranean-climate streams. Hydrobiologia 719, 59-75.

Hostens, K., J. Mees, 1999. The mysid-feeding guild of demersal fishes in the brackish zone of the Westerschelde estuary. Journal of Fish Biology 55: 704-719.

Ides, S., Plancke, Y., Vos, G., 2011. Validation of a 2-dimensional hydrodynamic model within a study to propose the optimal disposal strategy in the Western Scheldt. Houille blanche $3,36-41$.

Josefson, A.B., J.L.S. Hansen (2004). Species richness of benthic macrofauna in Danish estuaries and coastal areas. Global Ecology and Biogeography13, 273-288. 
Kristensen, E., Delefosse, M., Quintana, C.O., Flindt, M.R., Valdemarsen, T., 2014. Influence of benthic macrofauna community shifts on ecosystem functioning in shallow estuaries. Frontiers in Marine Science 1, 1-13.

Lambert, G. I., Jennings, S., Kaiser, M. J., Hinz, H., Hiddink, J. G. (2011). Quantification and prediction of the impact of fishing on epifaunal communities. Marine Ecology Progress Series, 430, 71-86.

Leonard, G.H., Levine, J.M., Schmidt, P.R., Bertness, M.D., 1998. Flow-driven variation in intertidal community structure in a Maine estuary. Ecology 79, 1395-1411.

Lytle, D.A., Poff, N.L. (2004. Adaptation to natural flow regimes. Trends in Ecology and Evolution 19, 94-100.

MarLIN, 2006. BIOTIC - Biological Traits Information Catalogue. Marine Life Information Network. Plymouth: Marine Biological Association of the United Kingdom. Available from http://www.marlin.ac.uk/biotic, accessed 1 August 2014.

Myers, N., Russell, A., Mittermeier, A., Mittermeier, C.G., da Fonseca, G.A.B., Kent, J., 2000. Biodiversity hotspots for conservation priorities. Nature 403, 853-858.

Oksanen, J. F.G. Blanchet, M. Friendly, R. Kindt, P. Legendre, D. McGlinn, P.R. Minchin, R. B. O'Hara, G. L. Simpson, P.Solymos, M. H.H. Stevens, E. Szoecs, H.Wagner (2017). Vegan: community ecology package. Version 2.4-3. Available from https://cran.rstudio.com/web/packages/vegan/index.html, accessed 27 May 2017.

Pearson, T.H., Rosenberg, R., 1978. Macrobenthic succession in relation to organic enrichment and pollution of the marine environment. Oceanography and Marine Biology: an Annual Review 16, 229-311.

Plancke, Y., Beirinckx, K., Liek, G.-J., Vos, G., Schrijver, M., 2014. A new disposal strategy in the Westerschelde, conciliating port accessibiliyt and nature. PIANC World Congress, San Francesco, USA.

Puente, A. Diaz, R.J. (2008). Is it possible to assess the ecological status of highly stressed natural estuarine environments using macroinvertebrates indices? Marine Pollution Bulletin 56: 1880-1889.

Remane, A. 1934. Die Brackwasserfauna. Verhandlungen Der Deutschen Zoologischen Gesellschaft, 36, 34-74.

Riisgard, H.U., Lassen, J., Kortegaard, M., Moeller, L.F., Friedrichs, M., Jensen, M.H., Larsen P.S., 2007. Interplay between filter-feeding zoobenthos and hydrodynamics in the shallow Odense Fjord (Denmark) - Earlier and recent studies, perspectives and modelling. Estuarine, Coastal and Shelf Science 75, 281-295. 
Robertson, B.P., Gardner, J.P.A., Savage, C. (2015). Macrobenthic-mud relations strengthen the foundation for benthic index development: a case study from shallow, temperate New Zealand estuaries. Ecological indicators 58, 151-174.

Rosenberg, R., 1995. Benthic marine fauna structured by hydrodynamic processes and food availability. Netherlands Journal of Sea Research 34, 303-317.

Sakamoto, Y., Ishiguro, M., Kitagawa, G., 1986. Akaike Information Criterion Statistics. Reidel, Dordrecht.

Schaffner, L.C., Dellapenna, T.M., Hinchey, E.K., Friedrichs, C.T., Neubauer, M.T., Smith, M.E., Kuehl, S.A. 2001. Physical energy regimes, sea-bed dynamics and organismsediment interactions along an estuarine gradient. In: Aller, J.Y., Woodin, S.A., Aller R.C. (eds.), Organism-Sediment Interactions. University of South Carolina Press, Columbia, SC, 161-182.

Schückel, U., Beck, M. Kröncke, I., 2015. Macrofauna communities of tidal channels in Jade Bay (German Wadden Sea): spatial patterns, relationships with environmental characteristics, and comparative aspects. Marine Biodiversity 45: 841. 841-855

Snelgrove, P.V.R., Butman, C.A., 1994. Animal-sediment relationships revisited: cause versus effect. Oceanogr. Marine Biology Annual Reviews 32, 111-177.

Statzner, B., Higler, B., 1986. Stream hydraulics as a major determinant of benthic invertebrate zonation patterns. Freshwater Biology 16, 127-139.

Stuart-Smith, R.D., Bates, A.E., Lefcheck, J.S., Duffy, J.E., Baker, S.C., Thomson, R.J., StuartSmith, J.F., Hill, N.A., Kininmonth, S.J., Airoldi, L., Becerro, M.A., Campbell, S.J., Dawson, T.P., Navarrete, S.A., Soler, G.A., Strain, E.M.A., Willis, T.J., Edgar, G.J., 2013. Integrating abundance and functional traits reveals new global hotspots of fish diversity. Nature 501, 539-541.

van Colen, C., De Backer, A., Meulepas, G., van der Wal, D., Vincx, M., Degraer, S., Ysebaert, T., 2010. Diversity, trait displacements and shifts in assemblage structure of tidal flat deposit feeders along a gradient of hydrodynamic stress. Marine Ecology Progress Series 406, 79-89.

van der Linden, P., Patrício, J., Marchini, A., Cid, N., Neto, J.M., , Marques, J.C., 2012. A biological trait approach to assess the functional composition of subtidal benthic communities in an estuarine ecosystem. Ecological Indicators 20, 121-133.

van der Wal, D., Herman, P.M.J., Forster, R.M., Ysebaert, T., Rossi, F., Knaeps, E., Plancke, Y.M.G., Ides, S.J., 2008. Distribution and dynamics of intertidal macrobenthos 
predicted from remote sensing: response to microphytobenthos and environment. Marine Ecology Progress Series 367, 57-72.

van der Wal, D., Forster, R.M., Rossi, F., Hummel, H., Ysebaert, T., Roose, F., Herman, P.M.J., 2011. Ecological evaluation of an experimental beneficial use scheme for dredged sediment disposal in shallow tidal waters. Marine Pollution Bulletin 62, 99108.

Warwick, M., Uncles, R.J., 1980. Distribution of benthic macrofauna associations in the Bristol Channel in relation to tidal stress. Marine Ecology Progress Series 3, 197-103.

Whitfield, A.K., Elliott, M., Basset, A., Blaber, S.J.M., West, R.J. 2012. Paradigms in estuarine ecology - A review of the Remane diagram with a suggested revised model for estuaries. Estuarine, Coastal and Shelf Science 97, 78-90.

Wildish, D., Kristmanson, D., 1997. Benthic suspension feeders and flow. Cambridge University Press, Cambridge, UK, 410 pp.

Wildish, D.J., Kristmanson, D.D., 1979. Tidal energy and sublittoral macrobenthic animals in estuaries. Journal of the Fisheries Research Board of Canada 36, 1197-1206 .

WoRMS Editorial Board, 2014. World Register of Marine Species. Available from http://www.marinespecies.org. Last accessed 1 August 2014.

Ysebaert, T. Herman, P.M.J., 2002. Spatial and temporal variation in benthic macrofauna and relationships with environmental variables in an estuarine, intertidal soft sediment environment. Marine Ecology Progress Series 244, 105-124.

Ysebaert, T., Herman, P.M.J., Meire, P., Craeymeersch, J., Verbeek, H., Heip, C.H.R., 2003. Large-scale spatial patterns in estuaries: estuarine macrobenthic communities in the Schelde estuary, NW Europe. Estuarine, Coastal and Shelf Science 57, 335-355.

Ysebaert, T., Plancke, Y., Bolle, L., De Mesel, I., Vos, G., Wielemaker, A., Van der Wal, D., Herman, P.M.J., 2009. Habitatmapping Westerschelde - Deelrapport 2: Ecologische karakteristieken en ecotopen in het subtidaal van de Westerschelde. Studie in opdracht van LTV O\&M. Report. Netherlands Institute of Ecology, Yerseke, 106 pp. (in Dutch, www.vliz.be/imisdocs/publications/217374.pdf)) 


\section{TABLES}

Table 1. Statistical summary of univariate macrofauna indices and environmental characteristics. $Z=$ elevation, $V=$ maximum current velocity at spring tide, $d 50=$ median grain-size, $C=$ organic carbon percentage of the sediment, $D=$ distance to intertidal area, $S=$ salinity. Statistics of untransformed density, biomass and species richness are given between parentheses. Statistics are based on $n=194$ stations for all variables.

\begin{tabular}{|c|c|c|c|c|c|}
\hline Variable & Unit & Mean & $S E$ & Min & Max \\
\hline \multicolumn{6}{|l|}{ Macrofauna } \\
\hline Ln (Density+1) & $\ln \left(\right.$ ind $\left.\mathrm{m}^{-2}\right)$ & 5.69 & 0.10 & 0 & 9.42 \\
\hline Density & (ind $\mathrm{m}^{-2}$ ) & (878.02) & (130.09) & (0) & (12364.36) \\
\hline Ln (Biomass +1$)$ & $\ln \left(\mathrm{mg} \mathrm{m}^{-2}\right)$ & 6.97 & 0.16 & 0 & 12.66 \\
\hline Biomass & $\left(\mathrm{mg} \mathrm{m}^{-2}\right)$ & (9706.72) & $(2152.50)$ & (0) & (314458.96) \\
\hline Ln(Species richness +1$)$ & - & 2.03 & 0.04 & 0.00 & 3.61 \\
\hline Species richness & - & (7.73) & $(0.35)$ & (0) & (36) \\
\hline Ecological richness & - & 0.00 & 0.07 & -3.69 & 2.52 \\
\hline \multicolumn{6}{|l|}{ Environment } \\
\hline$Z$ & $\mathrm{~m}$ & -5.11 & 0.19 & -12.30 & -0.93 \\
\hline$V$ & $\mathrm{~cm} \mathrm{~s}^{-1}$ & 117.66 & 2.50 & 48.83 & 210.01 \\
\hline$d 50$ & $\mu \mathrm{m}$ & 225.41 & 6.01 & 19.65 & 523.37 \\
\hline$C$ & $\%$ & 0.14 & 0.02 & 0.02 & 2.03 \\
\hline$D$ & $\mathrm{~m}$ & 249 & 21 & 0 & 1883 \\
\hline$S$ & - & 23.9 & 0.2 & 16 & 29 \\
\hline
\end{tabular}


Table 2. Taxonomic classification and functional traits of common taxa (see text for sources), with feeding mode ( $S D F=$ Surface deposit feeder, $D F=$ Deposit feeder, $S F=$ Suspension feeder, $C=$ Carnivorous, $O=$ Omnivorous $)$, mobility of adults ( $B=$ burrower, $C=$ crawler,$S=$ swimmer, $A=$ attached/sessile), life history strategy (ecological groups EG-I to EG-V) and U=unknown trait modality. Averaged (log-transformed) density (ind $\mathrm{m}^{-2}$ ) and biomass (AFDW $\mathrm{mg} \mathrm{m}^{-2}$ ), and occurrence (percentage out of 194 stations) of taxa are also shown. The 16 taxa listed account for $87 \%$ of the total density and $70 \%$ of the total biomass.

\begin{tabular}{|c|c|c|c|c|c|c|c|c|c|c|}
\hline Taxon & Phylum & Class & $\begin{array}{l}\text { Fee- } \\
\text { ding }\end{array}$ & Mobility & $\begin{array}{l}\text { Life } \\
\text { history }\end{array}$ & $\begin{array}{l}\text { Mean } \\
\text { density }\end{array}$ & $\begin{array}{l}\text { Mean ln } \\
\text { density }\end{array}$ & $\begin{array}{l}\text { Mean } \\
\text { biomass }\end{array}$ & $\begin{array}{l}\text { Mean } \ln \\
\text { biomass }\end{array}$ & $\begin{array}{l}\% \\
\text { stations }\end{array}$ \\
\hline Aphelochaeta marioni & Annelida & Polychaeta & SDF & B & IV & 249.41 & 1.79 & 30.44 & 0.96 & 38 \\
\hline Capitella (capitata) & Annelida & Polychaeta & DF & B & $\mathrm{V}$ & 19.78 & 1.15 & 29.88 & 0.51 & 32 \\
\hline Ensis (directus) & Mollusca & Bivalvia & SF & B & I & 4.93 & 0.44 & 5560.12 & 1.23 & 13 \\
\hline Eteone (longa) & Annelida & Polychaeta & $\mathrm{C}$ & BCS & III & 3.60 & 0.44 & 1.41 & 0.26 & 13 \\
\hline Gastrosaccus (spinifer) & Arthropoda & Malacostraca & $\mathrm{C}$ & BCS & II & 5.26 & 0.42 & 11.22 & 0.43 & 12 \\
\hline Heteromastus filiformis & Annelida & Polychaeta & DF & B & IV & 284.30 & 2.88 & 584.8 & 3.27 & 68 \\
\hline Limecola balthica & Mollusca & Bivalvia & SDF & $\mathrm{BC}$ & III & 25.44 & 1.46 & 716.81 & 2.49 & 40 \\
\hline Magelona spp. & Annelida & Polychaeta & SDF & B & I & 9.19 & 0.94 & 10.29 & 0.82 & 29 \\
\hline NEMERTEA & Nemertea & - & $\mathrm{C}$ & $\mathrm{U}$ & III & 7.73 & 0.51 & 4.74 & 0.29 & 15 \\
\hline Nephtys spp. & Annelida & Polychaeta & $\mathrm{O}$ & BCS & II & 38.83 & 2.88 & 230.61 & 3.62 & 79 \\
\hline OLIGOCHAETA & Annelida & Clitellata & DF & $\mathrm{U}$ & $\mathrm{V}$ & 18.31 & 0.88 & 0.36 & 0.15 & 24 \\
\hline Pygospio elegans & Annelida & Polychaeta & SDF & B & III & 3.80 & 0.45 & 0.20 & 0.11 & 14 \\
\hline Scoloplos armiger & Annelida & Polychaeta & SDF & B & III & 78.39 & 2.44 & 193.26 & 2.78 & 61 \\
\hline Spio spp. & Annelida & Polychaeta & SDF & B & III & 19.65 & 1.49 & 1.68 & 0.53 & 43 \\
\hline Spiophanes bombyx & Annelida & Polychaeta & SDF & B & III & 20.98 & 1.01 & 6.20 & 0.63 & 27 \\
\hline Tellinoidea & Mollusca & Bivalvia & DF & $\mathrm{U}$ & $\mathrm{U}$ & 3.26 & 0.46 & 0.41 & 0.18 & 15 \\
\hline
\end{tabular}


Table 3. Multivariate analyses: Spearman rank correlation $\rho$ of the macrofaunal community (total composition and functional trait compositions, density-and biomass based, respectively) and (combinations of) environmental variables $(Z=$ elevation, $v=$ maximum current velocity at spring tide, $d 50=$ median grain-size, $C=$ organic carbon percentage of the sediment, $D=$ distance to intertidal area, and $S=$ salinity). Bold figures show best models for single variables per response variable. Model with all environmental variables and the best stepwise search models with multiple environmental variables are also shown. Significant $(P<0.05, n=194)$ effects are marked *** for $P \leq 0.001$, ** for $P$ between 0.001 and 0.01 and * for P between 0.01 and 0.05 .

\begin{tabular}{|c|c|c|c|c|c|c|c|c|}
\hline \multirow{3}{*}{$\begin{array}{l}\text { Explanatory } \\
\text { environmental } \\
\text { variable }\end{array}$} & \multicolumn{8}{|c|}{ Response variable } \\
\hline & \multicolumn{2}{|c|}{ Total community } & \multicolumn{2}{|c|}{ Feeding habit } & \multicolumn{2}{|l|}{ Mobility } & \multicolumn{2}{|c|}{ Life history } \\
\hline & lnden & lnbio & lnden & lnbio & lnden & lnbio & lnden & lnbio \\
\hline \multicolumn{9}{|l|}{ Single variables } \\
\hline $\mathrm{z}$ & $0.129 * * *$ & $0.096^{* *}$ & $0.141 * * *$ & $0.097 * *$ & $0.100 * *$ & $0.073^{*}$ & $0.107 * *$ & $0.102 * * *$ \\
\hline $\mathrm{v}$ & $0.310 * * *$ & $0.276 * * *$ & $0.217 * * *$ & $0.194 * * *$ & $0.235^{* * * *}$ & $0.181 * * *$ & $0.207 * * *$ & $0.230 * * *$ \\
\hline d50 & $0.317 * * *$ & $0.259 * * *$ & $0.255^{* * * *}$ & $0.172 * * *$ & $0.238 * * *$ & $0.139 * * *$ & $0.230 * * *$ & $0.213 * * *$ \\
\hline $\mathrm{C}$ & $0.100 *$ & $0.097 *$ & $0.107 * *$ & 0.026 & $0.087 *$ & 0.020 & $0.173 * * *$ & $0.093 *$ \\
\hline D & $0.221 * * *$ & $0.188 * * *$ & $0.136^{* *}$ & $0.119^{* *}$ & $0.114 * *$ & $0.102 * *$ & $0.098 * *$ & $0.120 * *$ \\
\hline S & $0.086^{* *}$ & $0.109 * * *$ & -0.007 & 0.018 & -0.010 & 0.02 & 0.007 & 0.039 \\
\hline $\begin{array}{l}\text { Multiple variab } \\
\mathrm{z}, \mathrm{v}, \mathrm{d} 50, \mathrm{C}, \mathrm{D}, \mathrm{S} \\
\text { (all) }\end{array}$ & $0.353 * * *$ & $0.306^{* * *}$ & $0.244 * * *$ & $0.175^{* * *}$ & $0.204 * * *$ & $0.139 * * *$ & $0.228 * * *$ & $0.227 * * *$ \\
\hline $\mathrm{v}, \mathrm{d} 50, \mathrm{D}$ & $0.397 * * *$ & & & & & & & \\
\hline $\mathrm{v}, \mathrm{d} 50, \mathrm{D}, \mathrm{S}$ & & $0.344 * * *$ & & & & & & \\
\hline $\mathrm{v}, \mathrm{d} 50, \mathrm{Z}$ & & & $0.293 * * *$ & & & & $0.281 * * *$ & \\
\hline $\mathrm{v}, \mathrm{d} 50$ & & & & $0.218 * * *$ & $0.290 * * *$ & $0.189 * * *$ & & $0.271 * * *$ \\
\hline
\end{tabular}


Table 4. Univariate analyses: linear single and multiple regression of log-transformed density (ind $\left./ \mathrm{m}^{2}\right)$, log-transformed biomass $\left(\mathrm{mg} / \mathrm{m}^{2}\right)$, log-transformed species richness and ecological richness of the macrofauna on the environmental variables. $R^{2}$ is shown for single variables, $R^{2}{ }_{a d j}$ is shown for best models with multiple variables. See caption for Table 1 for explanation of variables. Bold figures show best models for single variables. Significant $(P<0.05, n=194)$ regressions are marked *** for $P \leq 0.001$, ** for $P$ between 0.001 and 0.01 and * for $P$ between 0.01 and 0.05 . Significant $(P<0.05)$ heteroscedasticy is marked $x$, non-normality of residuals is marked $w$, and autocorrelated residuals are marked $d$.

\begin{tabular}{|c|c|c|c|c|c|c|c|c|}
\hline & \multicolumn{8}{|c|}{ Response variable } \\
\hline & \multicolumn{2}{|c|}{ Ln density } & \multicolumn{2}{|c|}{ Ln biomass } & \multicolumn{2}{|c|}{$\begin{array}{l}\text { Ln species } \\
\text { richness }\end{array}$} & \multicolumn{2}{|c|}{ Ecological richness } \\
\hline $\begin{array}{l}\text { Environmental } \\
\text { variable }\end{array}$ & \multicolumn{2}{|c|}{$\begin{array}{l}R^{2}(\text { single }) \text { or } \\
R_{\text {adj }}^{2}(\text { multiple })\end{array}$} & \multicolumn{2}{|c|}{$\begin{array}{l}R^{2}(\text { single }) \text { or } \\
\left.R_{\text {adj }}^{2} \text { (multiple }\right) \\
\end{array}$} & \multicolumn{2}{|c|}{$\begin{array}{l}R^{2}(\text { single }) \text { or } \\
R_{\text {adj }}^{2} \text { (multiple) }\end{array}$} & \multicolumn{2}{|c|}{$\begin{array}{l}R^{2}(\text { single }) \text { or } \\
R_{\text {adj }}^{2}(\text { multiple })\end{array}$} \\
\hline \multicolumn{9}{|c|}{ Single variables (simple linear regression) } \\
\hline$Z$ & $0.09 * * *$ & w & $0.06 * * *$ & $\mathrm{~d}$ & $0.12 * * *$ & w & $0.11 * * *$ & \\
\hline$v$ & $0.30 * * *$ & w & $0.29 * * *$ & & $0.33 * * *$ & & $0.37 * * *$ & \\
\hline$d 50$ & $0.24 * * *$ & $\mathrm{x}, \mathrm{w}$ & $0.14 * * *$ & $\mathrm{~d}, \mathrm{w}$ & $0.18 * * *$ & W & $0.22 * * *$ & $\mathrm{X}, \mathrm{W}$ \\
\hline$C$ & $0.09 * * *$ & $\mathrm{x}, \mathrm{W}$ & 0.00 & d & 0.00 & w & $0.02 *$ & \\
\hline$D$ & $0.10 * * *$ & $\mathrm{w}$ & $0.05 * *$ & d & $0.09 * * *$ & $\mathrm{w}$ & $0.10 * * *$ & \\
\hline$S$ & $0.04 * *$ & w & $0.05 * *$ & $\mathrm{~d}$ & $0.03 *$ & $\mathrm{x}, \mathrm{w}$ & $0.05 * *$ & $\mathrm{~W}$ \\
\hline \multicolumn{9}{|c|}{ Multiple variables (stepwise linear regression) } \\
\hline$z, v, d 50, C, S$ & $0.35 * * *$ & w & & & & & & \\
\hline$v, d 50, C$ & & & $0.31 * * *$ & & $0.37 * * *$ & $\mathrm{x}, \mathrm{w}$ & $0.39 * * *$ & $\mathrm{~W}$ \\
\hline
\end{tabular}




\section{FIGURES}

Figure 1. (a) Westerschelde, southwest Netherlands and (b) localities within the Westerschelde. Samples are indicated with black dots. Background grey are channels $<-10 m$ NAP, mid grey is subtidal area between -10 and $-5 m$ NAP, light grey is subtidal area between -5 and -2m NAP, white is intertidal area (>-2m NAP) and beige is land. The study site covers the polyhaline zone (salinity 18-30), and a small part of the mesohaline zone (salinity <-18, indicated with forward hatches). Tidal flat and shoals are named as follows: HP (Hooge Platen), SP (Spijkerplaat), LS (Lage Springer), MS (Mosselplaat), MI (Middelplaat), PE (Plaat van Everingen), PB (Plaat van Baarland), RB (Rug van Baarland), MP (Molenplaat), and PO (Plaat van Ossenisse) and PW (Plaat van Walsoorden).
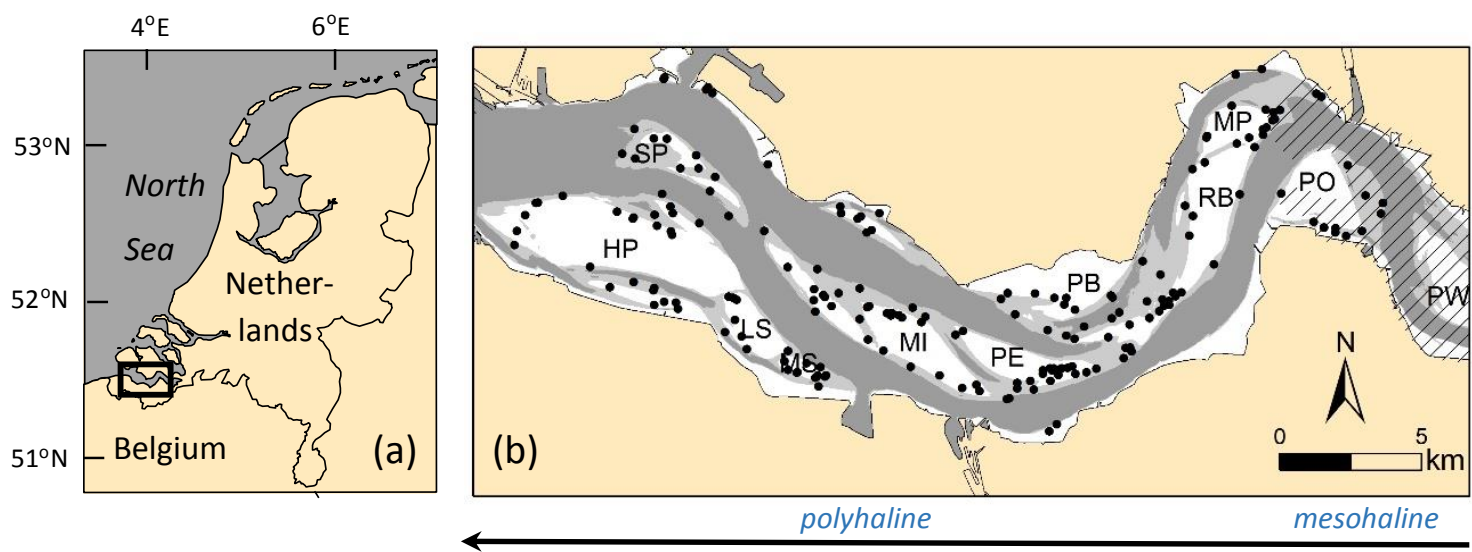

salinity gradient 
Figure 2. Log-transformed density (ind $\left.\mathrm{m}^{-2}\right)$ and biomass $\left(\mathrm{mg} / \mathrm{m}^{-2}\right)$ of $(a, b)$ feeding habit, $(c, d)$ mobility traits, and (e,f) life history strategy, versus maximum current velocity to highlight overall trends. Thick lines are linear regression models based on 194 sample observations (not shown here) and shaded areas show the 95\% confidence interval of the regression, for significant $(P<0.05)$ models only. Horizontal lines show the ranges of 10 current velocity classes with ca 20 sample observations each and vertical lines show the 95\% confidence interval of the mean of each class.
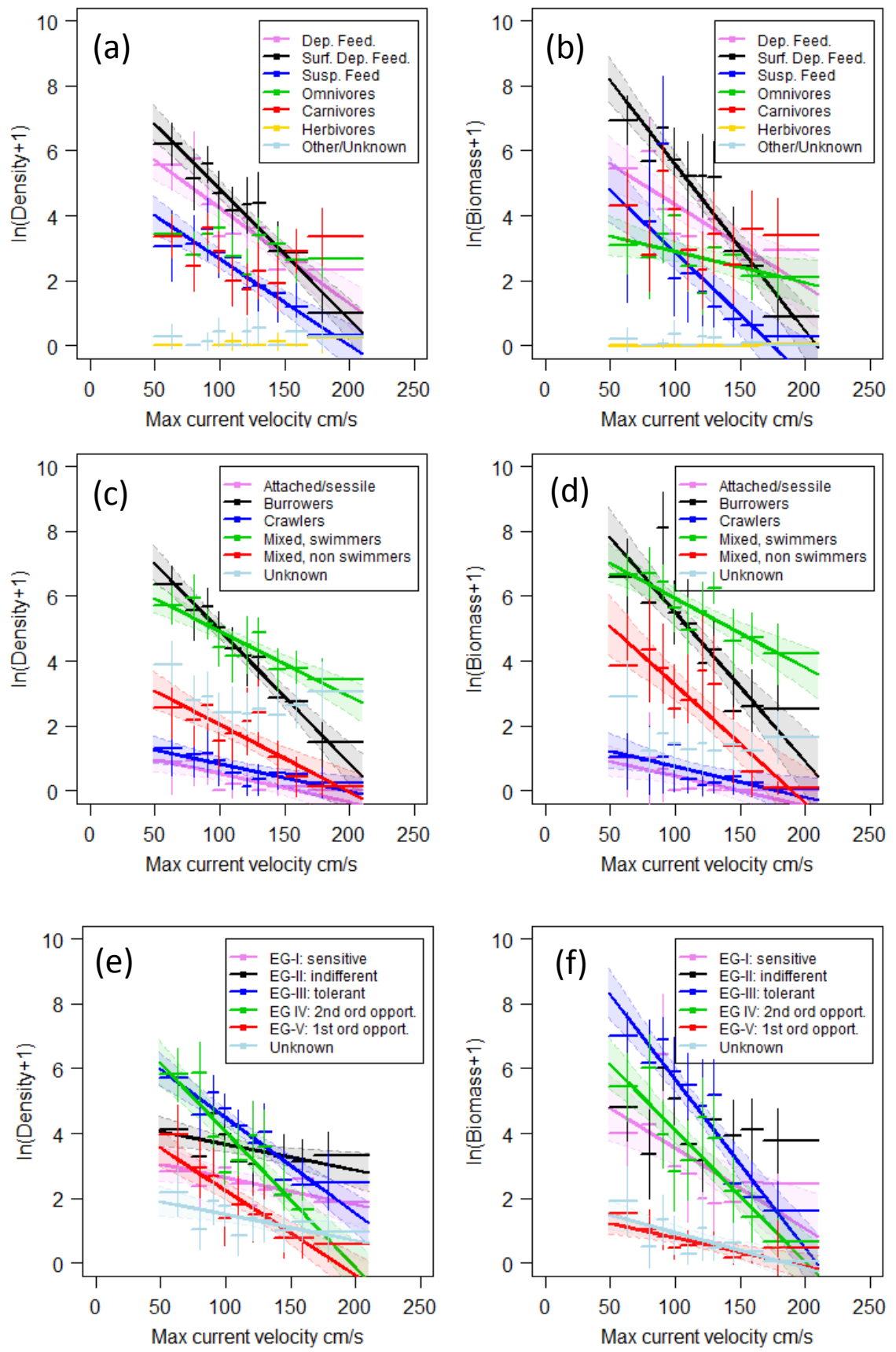
Figure 3. Log-transformed density (ind $\left.\mathrm{m}^{-2}\right)$ and biomass $\left(\mathrm{mg} \mathrm{m}^{-2}\right)$ of $(a, b)$ feeding habit, $(c, d)$ mobility traits and $(e, f)$ life history strategy, versus median grain-size of the sediment to highlight overall trends. Thick lines are linear regression models based on 194 sample observations (not shown here) and shaded areas show the 95\% confidence interval of the regression, for significant $(P<0.05)$ models only. Horizontal lines show the ranges of 10 median grain-size classes with ca 20 sample observations each and vertical lines show the $95 \%$ confidence interval of the mean of each class.
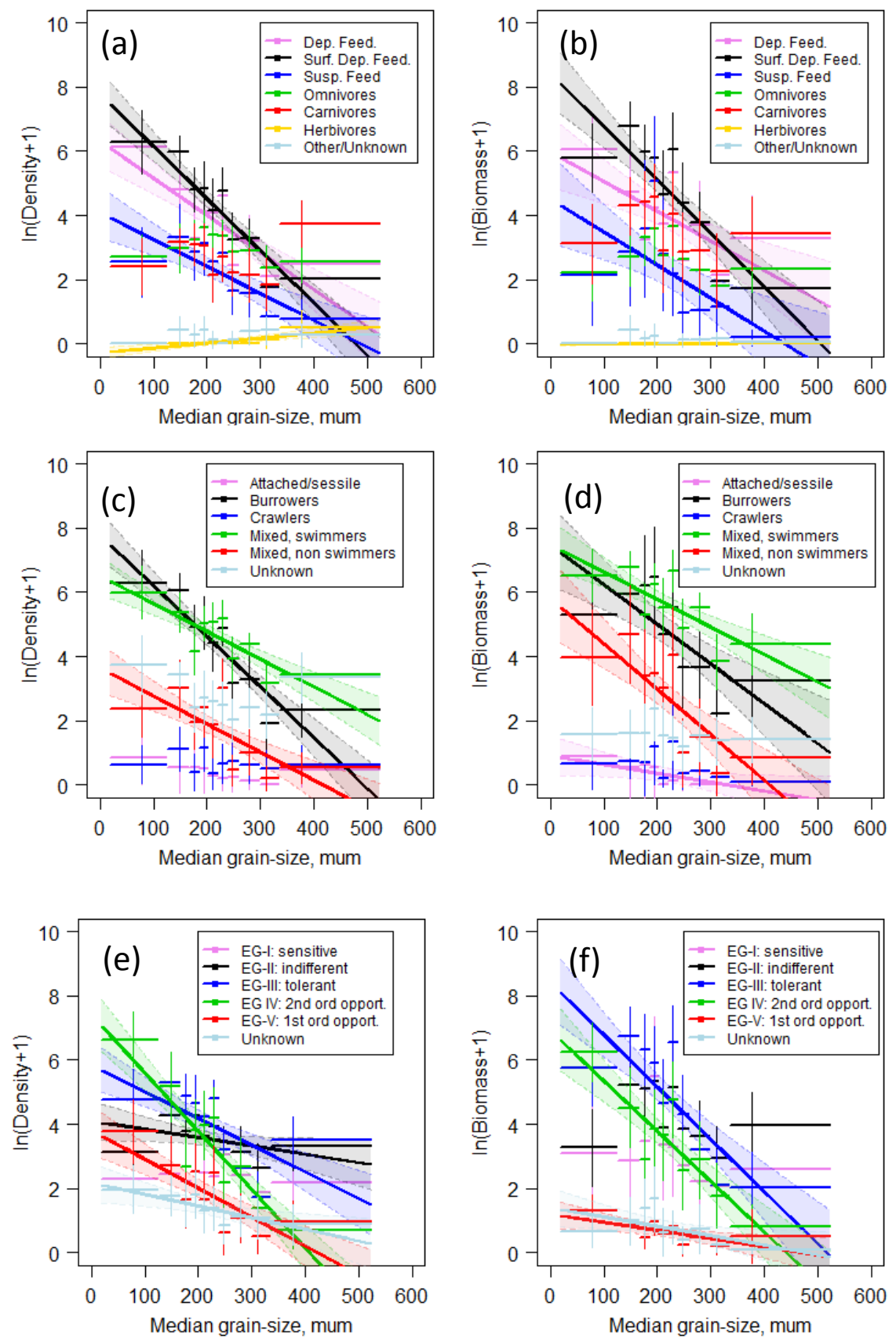
Figure 4. (a) Model estimate of ecological richness (composite measure of high density, biomass and species richness) of the zone -2 to -10 m NAP based on maximum current velocity. Dots show observations of ecological richness in the same color scale. Grey areas indicate channels (<-10m NAP); white areas are intertidal areas (>-2m NAP) and beige areas are land, (b) spatial clustering of observed ecological richness based on Anselin local Moran's I. Large red stars give statistically significant hotspots $(H H)$, large blue triangles give significant coldspots (LL). Light orange stars are identified as high outliers in areas with low values $(H L)$ and light blue triangles are identified as low outliers in an area with high values (LH). Black dots have no significant clustering. Background colours in (b) as in Fig. 1 b.
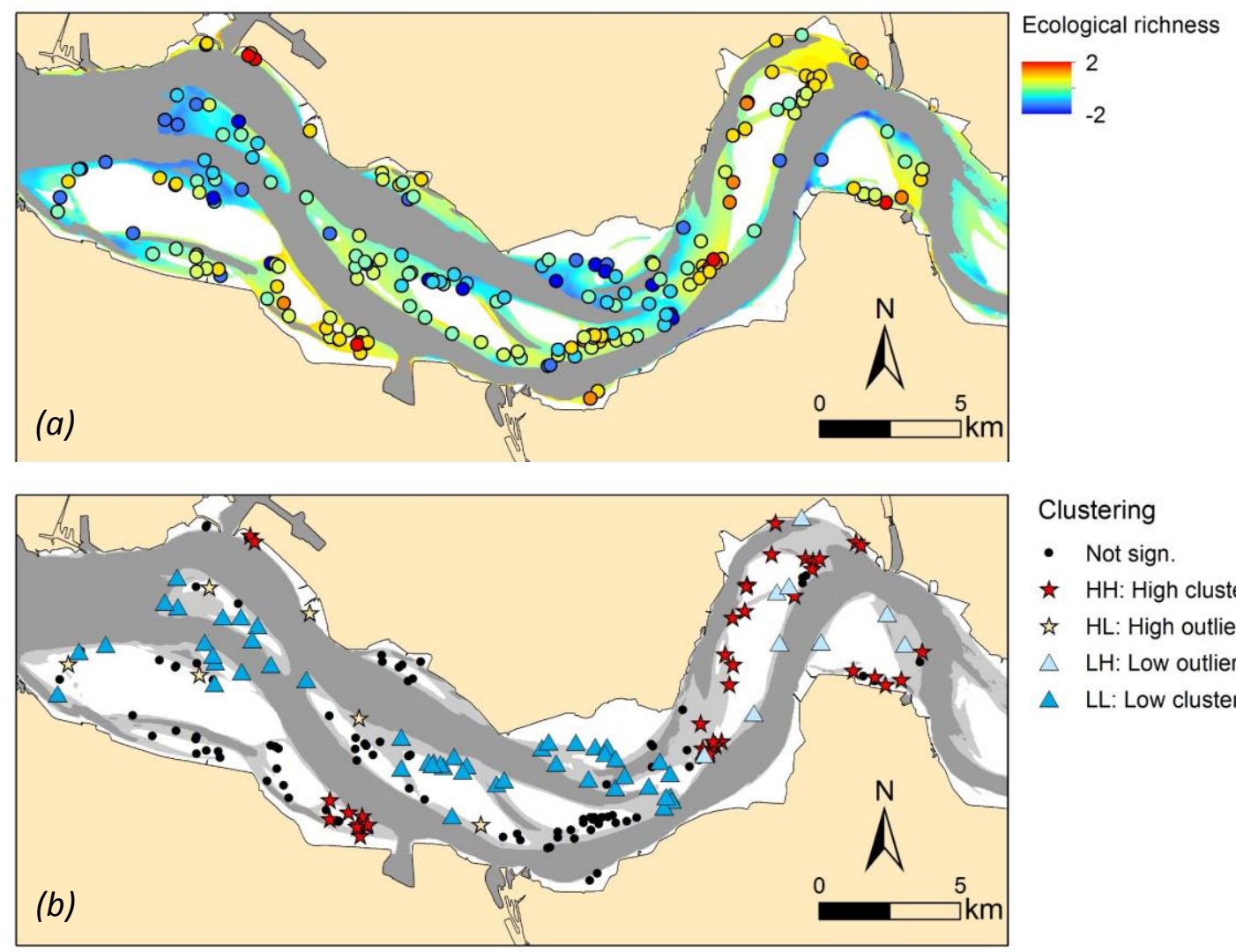

Clustering

- Not sign.

$\star \mathrm{HH}$ : High clusters (hotspots)

is HL: High outlier

$\triangle$ LH: Low outlier

$\Delta$ LL: Low clusters (coldspots) 
Van der Wal, D., G.I. Lambert, T. Ysebaert, Y.M.G. Plancke, P.M.J Herman (2017). Hydrodynamic conditioning of diversity and functional traits in subtidal estuarine macrozoobenthic communities, Estuarine, Coastal and Shelf Science 197, 80-92. https://doi.org/10.1016/j.ecss.2017.08.012.

\title{
SUPPLEMENTARY MATERIAL
}

\section{Hydrodynamic conditioning of diversity and functional traits in subtidal estuarine macrozoobenthic communities}

\author{
Daphne van der Wal $^{a^{*}}$, Gwladys I. Lambert ${ }^{a, b}$, Tom Ysebaert ${ }^{a}$, \\ Yves M.G. Plancke ${ }^{d}$,Peter M.J. Herman ${ }^{a, e}$
}

${ }^{a}$ NIOZ Royal Netherlands Institute of Sea Research, Dept of Estuarine and Delta Systems, and Utrecht University, P.O. Box 140, 4400 AC Yerseke, The Netherlands

${ }^{b}$ School of Ocean Sciences, Bangor University, Menai Bridge, Anglesey LL59 5AB, United Kingdom

${ }^{c}$ Wageningen Marine Research, P.O.Box 77, 4400 AB Yerseke, The Netherlands

${ }^{d}$ Flanders Hydraulics Research, Flemish Government, Borgerhout, Antwerpen, Belgium,

${ }^{e}$ Presently at Deltares, P.O. Box 177, 2600 MH Delft, The Netherlands

*Corresponding author: daphne.van.der.wal@nioz.nl 


\section{Supplementary Material S1}

A permutational multivariate analysis of variance using a Euclidean distance matrix. Logtransformed density and biomass ot the macrofauna community, respectively are expressed as function of the normalized environmental variables elevation (z), maximum current velocity (v), median grain-size d50, organic carbon percentage of the sediment $C$, distance to the tidal flat $(D)$ and salinity $(S)$. Significant $(P<0.05, n=194)$ effects (999 permutations) are marked *** for $P \leq 0.001$, ** for $P$ between 0.001 and 0.01 and * for $P$ between 0.01 and 0.05 .

\begin{tabular}{|c|c|c|c|c|c|}
\hline & $d f$ & SumOfSqs & MeanSqs & $F$ & $R^{2}$ \\
\hline \multicolumn{6}{|c|}{ Community based on ln (Density +1$)$} \\
\hline$Z$ & 1 & 524.8 & 524.78 & 10.3552 & $0.04239 * * *$ \\
\hline$V$ & 1 & 1004.8 & 1004.80 & 19.8273 & $0.08116 * * *$ \\
\hline D50 & 1 & 468.3 & 468.30 & 9.2408 & $0.03783 * * *$ \\
\hline C & 1 & 385.6 & 385.62 & 7.6092 & $0.03115 * * *$ \\
\hline$D$ & 1 & 55.1 & 55.07 & 1.0867 & 0.00445 \\
\hline$S$ & 1 & 464.6 & 464.64 & 9.1686 & $0.03753 * * *$ \\
\hline Residuals & 187 & 9476.7 & 50.68 & & 0.76549 \\
\hline Total & 193 & 12379.9 & & & 1.00000 \\
\hline \multicolumn{6}{|c|}{ Community based on $\ln ($ Biomass +1$)$} \\
\hline Z & 1 & 409.8 & 409.79 & 6.4404 & $0.02748 * * *$ \\
\hline$V$ & 1 & 1129.7 & 1129.67 & 17.7543 & $0.07577 * * *$ \\
\hline D50 & 1 & 285.0 & 284.98 & 4.4789 & $0.01911 * * *$ \\
\hline$C$ & 1 & 400.2 & 400.20 & 6.2897 & $0.02684 * * *$ \\
\hline$D$ & 1 & 83.0 & 82.96 & 1.3038 & 0.00556 \\
\hline$S$ & 1 & 703.9 & 703.93 & 11.0633 & $0.04721 * * *$ \\
\hline Residuals & 187 & 11898.4 & 63.63 & & 0.79802 \\
\hline Total & 193 & 14909.9 & & & 1.00000 \\
\hline
\end{tabular}




\section{Supplementary Material S2}

Table showing ANOVA results for univariate macrofauna indices with factor strata (stations $<-5 m$ NAP, low dynamic stations >-5 $m$ NAP, and high dynamic stations >-5 $m$ NAP). Significant $(P<0.05, n=194)$ effects are marked $* * *$ for $P \leq 0.001$, ** for $P$ between 0.001 and 0.01 and * for P between 0.01 and 0.05. Tukey HSD tests confirm consistent significant differences between low and high dynamic stations >-5m NAP, and between stations $<-5 m$ NAP and low dynamic stations >-5m NAP, whereas differences between the dynamic stations $>-5 m$ NAP and stations $<-5 m$ NAP were consistently non-significant.

\begin{tabular}{lll}
\hline Variable & $d f$ & $F$ \\
\hline Ln (density +1$)$ & 2,191 & $18.61^{* * *}$ \\
Ln (biomass +1$)$ & 2,191 & $21.83^{* * *}$ \\
Ln (species richness +1$)$ & 2,191 & $20.21^{* * *}$ \\
Ecological richness & & \\
& 2,191 & $24.56^{* * *}$ \\
\hline
\end{tabular}




\section{Supplementary Material S3}

Figure showing log-transformed density (ind $\left.\mathrm{m}^{-2}\right)$, log-transformed biomass $\left(\mathrm{mg} \mathrm{m}^{-2}\right)$, logtransformed species richness and ecological richness versus environmental variables, with 194 observations (stations) and regression line (see Table 4 for details).
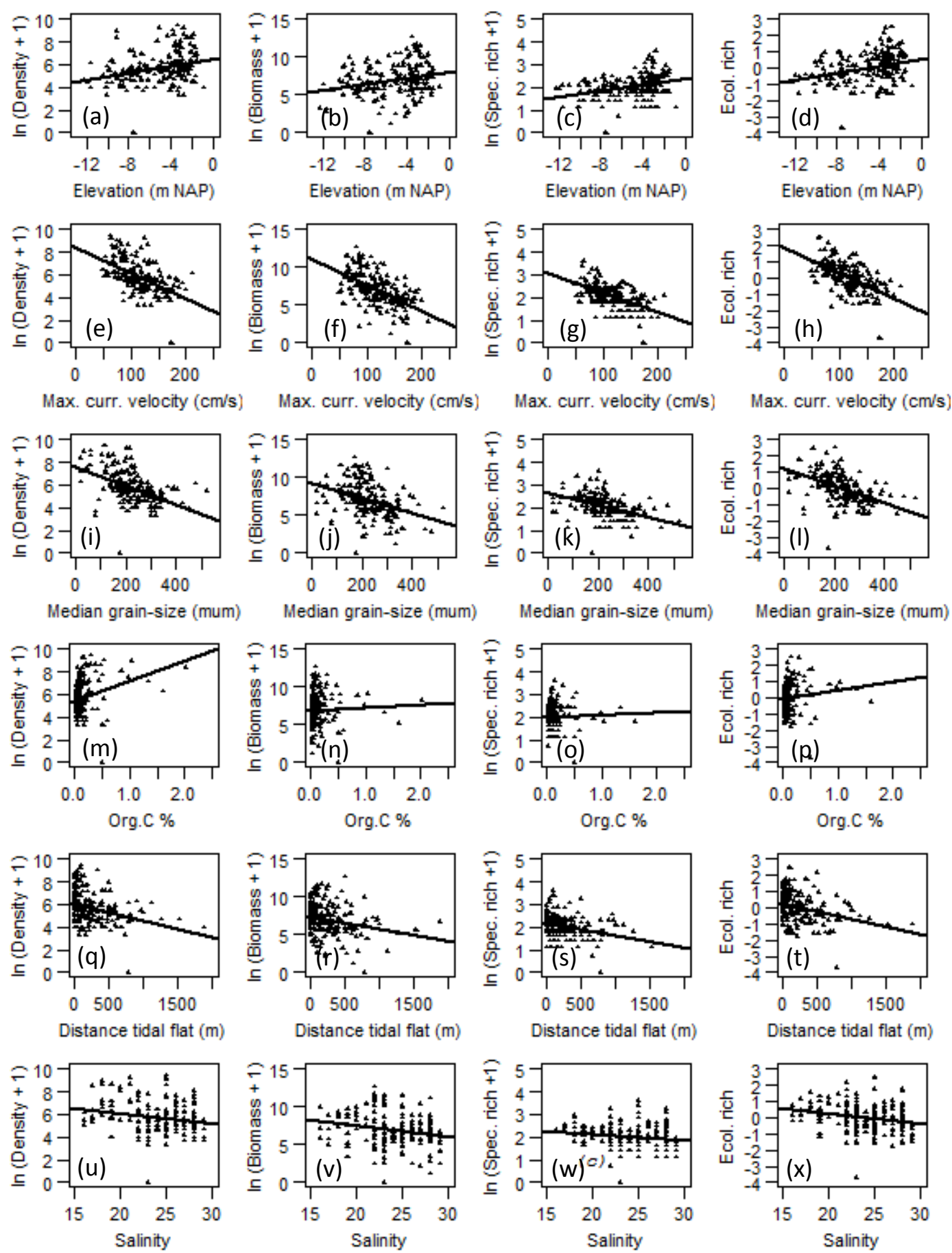


\section{Supplementary Material S4}

Table showing Pearson correlation coefficients between macrofauna indices log-transformed density (ln density +1), logtransformed biomass (ln biomass +1$)$, logtransformed species richness (ln species richness +1$)$ and ecological richness. Significant $(P<0.05, n=194)$ effects are marked *** for $P \leq 0.001$, ** for $P$ between 0.001 and 0.01 and * for $P$ between 0.01 and 0.05 .

\begin{tabular}{lllr}
\hline Macrofauna index & lnbio & $\ln S$ & \multicolumn{1}{c}{ Ecological richness } \\
\hline Ln $($ density +1$)$ & $0.73^{* * *}$ & $0.80^{* * *}$ & $0.93^{* * *}$ \\
Ln (biomass +1$)$ & & $0.72^{* * *}$ & $0.89^{* * *}$ \\
Ln (species richness +1$)$ & & $0.92^{* * *}$ \\
\hline
\end{tabular}




\section{Supplementary Material S5}

Table showing Pearson correlation coefficients between environmental variables. $z=$ elevation, $v=$ maximum current velocity at spring tide, $d 50=$ median grain-size,$C=$ organic carbon percentage, $D=$ distance to intertidal area, $S=$ salinity. Significant $(P<0.05, n=194)$ effects are marked *** for $P \leq 0.001$, ** for $P$ between 0.001 and 0.01 and * for $P$ between 0.01 and 0.05 .

\begin{tabular}{lllrrr}
\hline $\begin{array}{l}\text { Environmental } \\
\text { Variable }\end{array}$ & $v$ & $d 50$ & \multicolumn{2}{c}{$D$} & \multicolumn{2}{c}{$S$} \\
\hline$z$ & $-0.41^{* * *}$ & $-0.29^{* * *}$ & -0.02 & $-0.59^{* * * *}$ & 0.07 \\
$v$ & & $0.57^{* * *}$ & $-0.25^{* * *}$ & $0.43^{* * *}$ & $0.31^{* * *}$ \\
$d 50$ & & & $-0.58^{* * *}$ & $0.33^{* * *}$ & 0.09 \\
$C$ & & & & -0.14 & -0.06 \\
$D$ & & & & & 0.05 \\
\hline
\end{tabular}




\section{Supplementary Material S6}

Log-transformed density (ind $\left.\mathrm{m}^{-2}\right)$ and biomass $\left(\mathrm{mg} \mathrm{m}^{-2}\right)$ of $(a, b)$ feeding habit, $(c, d)$ mobility traits and $(e, f)$ life history strategy, versus organic carbon percentage of the sediment, highlighting overall trends. Thick lines are linear regression models based on 194 sample observations (not shown here) and shaded areas show the 95\% confidence interval of the regression, for significant $(P<0.05)$ models only. Horizontal lines show the ranges of 10 median grain-size classes with ca 20 sample observations each and vertical lines show the 95\% confidence interval of the mean of each class.
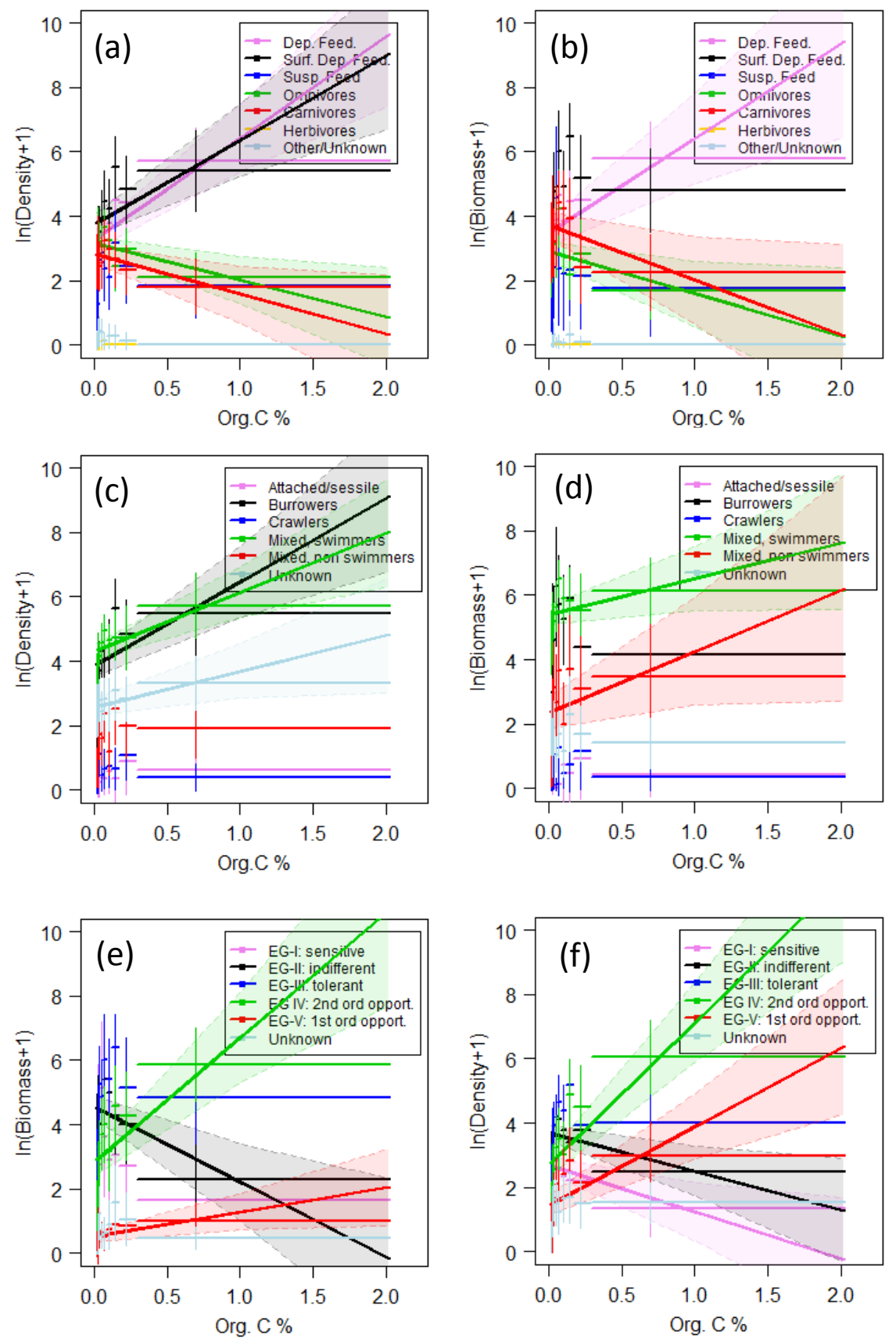


\section{Supplementary Material S7}

Contribution of taxa to (untransformed) density in each sample. Samples ( $n=194)$ were labelled according to the outcome of the spatial clustering, i.e., (a) non-significant clustering (n=91), (b) significant hotspots $H H(n=40)$ and high outliers $H L(n=6),(c)$ significant coldspots LL ( $n=47$ samples) and low outliers $L H$ ( $n=9$ samples). One LL sample without any macrofauna was omitted in the graph.
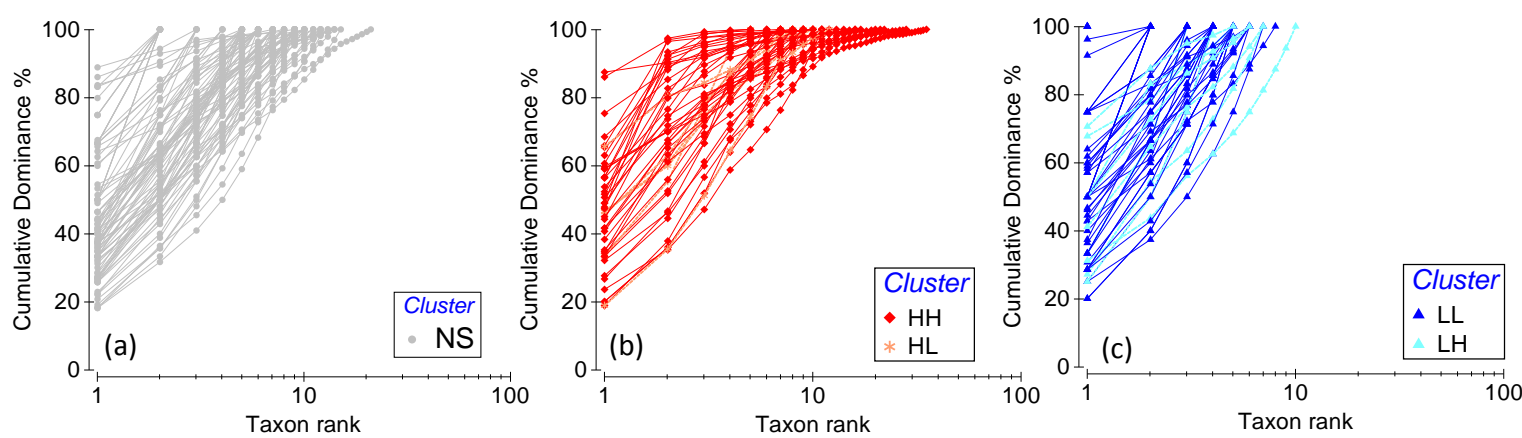